\title{
OPENING PANDORA'S BOX: SOVEREIGN BONDS IN INTERNATIONAL ARBITRATION
}

\author{
By Michael Waibel*
}

In recent years, sovereign debt crises have received much attention from the perspective of international public policy, but an effective legal solution to sovereign defaults has yet to coalesce within international law. Over the last two decades, private creditors have increasingly resorted to litigation in national courts, though without great success, in an effort to obtain payment on defaulted sovereign debt. Another, emerging option is arbitration - in particular, before the International Centre for Settlement of Investment Disputes (ICSID). Will ICSID be the new venue of choice for recovering on sovereign bonds? ${ }^{1}$ The conclusion reached here is that attempts to take defaulting countries to ICSID arbitration are unlikely to succeed. ${ }^{2}$

Government bonds are at the heart of public finance and play a central role in the development of capital markets. ${ }^{3}$ To developed and developing countries alike, bonds have long been the instrument of choice for raising long-term funds, domestically and internationally. In 2005, the international debt market amounted to almost U.S.\$30 trillion. ${ }^{4}$ Its magnitude

${ }^{*}$ Dr. iur. candidate, Universität Wien (Austria), and LL.M. candidate, Harvard Law School. I gratefully acknowledge generous financial support by the Austrian Academy of Sciences under its DOC scholarship program. Thomas Laryea sparked my interest in this topic and provided invaluable advice from start to finish. Damien Eastman and August Reinisch, my thesis adviser, gave extensive comments on earlier drafts. I owe thanks to David Berry, Charles Blitzer, Juan Pablo Bohoslavsky, William Burke-White, Marcos Chamon, Mark Cymrot, Anna Gelpern, Christopher Greenwood, Darshini Manraj, Alexis Martinez, Michael McMahon, Paul Oberhammer, Christoph Paulus, Maurizio Ragazzi, Stephan Schill, Brad Setser, David Skeel, Edwin Truman, Guglielmo Verdirame, Gottfried Waibel, Yeon-Jue Yoo, and Jeromin Zettelmeyer. I further thank Eric Robert for assistance in locating sources. Earlier versions of this article were presented at Cambridge University, the International Monetary Fund, and the Universität Zürich. The London School of Economics and the Lauterpacht Centre for International Law were stimulating environments to complete this article.

${ }^{1}$ The discussion is relevant not only for sovereign bonds, but also, more generally, for debt instruments and financial transactions. The recently registered "Italian Bondholder" arbitration, Beccarav. Argentine Republic, ICSID Case No. ARB/07/5 (registered Feb. 7, 2007), motivates the focus on ICSID. However, one should not discount that future bondholders could request arbitration under UNCITRAL rules if bonds incorporated such arbitration clauses.

Many of the ICSID decisions and awards discussed in this article are available at $<$ http://www.worldbank.org/ $\mathrm{icsid} /$ cases/cases.htm>.

${ }^{2}$ Earlier writers reached the contrary conclusion. See Peter Griffin \& Ania Farren, How ICSID Can Protect Sovereign Bondholders, 24 INT'L FIN. L. REV. 21 (2005); Alexander Szodruch, State Insolvency —Consequences and Obligations Under Investment Treaties, in THE INTERNATIONAL CONVENTION FOR THE SETTLEMENT OF INVESTMENT DISPUTES (ICSID): TAKING STOCK AFTER 40 YEARS 141 (Rainer Hofmann \& Christian Tams eds., 2007); Thomas W. Wälde, The Serbian Loans Case: A Precedent for Investment Treaty Protection of Foreign Debt? in INTERNATIONAL INVESTMENT LAW AND ARBITRATION: LEADING CASES FROM THE ICSID, NAFTA, BILATERAL TREATIES AND CUSTOMARY INTERNATIONAL LAW 383 (Todd Weiler ed., 2005) [hereinafter LEADING CASES].

${ }^{3}$ The term "sovereign bond" is abbreviated as "bond" in this article when there is no risk of confusion. For a fascinating account of the long history of sovereign bonds, see NIALL FERGUSON, THE CASH NEXUS: MONEY AND POWER IN THE MODERN WORLD, 1700-2000 (2001).

${ }^{4}$ This figure excludes domestic debt (owed to nationals). In 2005, the stock of international debt securities amounted to more than U.S.\$15.3 trillion, International Monetary Fund, Coordinated Portfolio Investment Survey 2005, tbl. 12.2, at $<$ http://www.imf.org/external/np/sta/pi/05/Table12_2.pdf $>$. Added to this amount is at least 
is more than double the United States' gross domestic product (GDP), or roughly half of world economic output. ${ }^{5}$

Countries' access to capital markets in the twentieth and twenty-first centuries has raised new questions for litigation against sovereigns. In the sovereign debt market, countries act much like private borrowers. Countries issue under municipal law and routinely waive immunity from jurisdiction in favor of foreign municipal courts. Sovereign bonds hence depart from traditional investment contracts, to which ICSID arbitration was tailored.

Periodic sovereign debt crises not only decrease welfare for countries and their populations; ${ }^{6}$ they threaten regional and, at times, global political and financial stability. Latin America experienced a decade-long debt crisis in the 1980s. In 1995, Mexico was unable to meet its external debt obligations. Three years later, a severe financial crisis hit East Asia. Russia defaulted in 1998. Argentina's 2001 default on more than U.S.\$100 billion in private debt was the largest in history. ${ }^{7}$ Meanwhile, the Heavily Indebted Poor Countries (HIPC) Initiative tackles chronic debt overhang in the world's poorest countries - especially in Africa. ${ }^{8}$

Countries with unsustainable debt burdens routinely restructure their public debt. Sovereign debt restructuring refers to the various techniques used by countries in financial distress to change the debt's original payment terms. ${ }^{9}$ The aim is a more manageable liability profile over time or a reduction in the debt's net present value. Bond exchanges are often used to restructure sovereign bonds. ${ }^{10}$ For sovereign issuers — unlike companies, which are able to reorganize in the shadow of corporate insolvency law_-such exchanges are presently among the few viable methods for reorganizing sovereign debt. ${ }^{11}$

U.S.\$14.19 trillion owed to commercial banks, BIS Q. REV., June 2006, statistical annex, tbl. 9A. Derivatives are not included in these figures.

${ }^{5}$ In 2006, U.S. GDP was \$U.S.13.19 trillion. U.S. Bureau of Economic Analysis, National Economic Accounts, $a t<\mathrm{http}: / /$ www.bea.gov/national/xls/gdplev.xls $>$. The U.S. share of world GDP is about 28 percent (in current U.S. dollars). The implied average external-debt/GDP ratio across countries is about 50 percent.

${ }^{6}$ Estimates of the numbers of sovereign defaults vary, but without doubt their incidence is high. ANDREW G. HALDANE, FIXING FINANCIAL CRISES IN THE TWENTY-FIRST CENTURY (2004), documents about 200 defaults since 1830. Carmen M. Reinhart \& Kenneth S. Rogoff, Serial Default and the "Paradox" of Rich-to-Poor Capital Flows, AM. ECON. REV. (PAPERS \& PROC.), May 2004, at 53, finds 125 defaults for a sample of twenty-three countries over the last five centuries.

7 ANDREAS F. LOWENFELD, INTERNATIONAL ECONOMIC LAW 566-616 (2002), surveys sovereign debt crises in the 1980s and 1990s. FEDERICO STURZENEGGER \& JEROMIN ZETTELMEYER, DEBT DEFAULTS AND LESSONS FROM A DECADE OF CRISES (2006), provides insight into the crises during 1998-2005.

${ }^{8}$ Initiated in 1996, the HIPC Initiative, modified as the Enhanced HIPC Initiative in 1999, has so far provided U.S.\$19 billion in debt relief. WORLD BANK AND INDEPENDENT EVALUATION GROUP, DEBT RELIEF FOR THE POOREST: AN EVALUATION UPDATE OF THE HIPC INITIATIVE (2006), at <http://www.worldbank.org/ieg/ hipc/>, provides an excellent overview. Private creditors do not consistently provide debt relief on par with the official sector. Id. at 14. A recent example is an English judgment against Zambia. Donegal Int'l Ltd. v. Republic of Zambia, [2007] EWHC (Comm) 197.

${ }^{9}$ STURZENEGGER \& ZETTELMEYER, supra note 7, at 3, defines debt restructurings as "changes in the originally envisaged debt service payments, either after a default or under the threat of default."

${ }^{10}$ A country experiencing payment difficulties offers new bonds in exchange for old debt instruments. Bank loans are typically rescheduled through the Bank Advisory Committee, or London Club, process-which unites a number of syndicate banks to conduct collective restructuring negotiations with the borrowing country. The Paris Club, an informal organization of major creditor governments, restructures official debt. LEX RIEFFEL, RESTRUCTURING SOVEREIGN DEBT: THE CASE FOR AD HOC MACHINERY (2003), has a detailed overview.

${ }^{11}$ In 2001, the International Monetary Fund proposed a new sovereign debt restructurings mechanism (SDRM), ANNE O. KRUEGER, A NEW APPROACH TO SOVEREIGN DEBT RESTRUCTURING (2002), but the proposal failed to garner sufficient support. Sovereign bankruptcy proposals have had currency in the academic 
The feasibility of arbitrating sovereign debt instruments is of major policy significance, and the need for effective mechanisms to resolve sovereign debt crises is evident. Sovereign defaults invariably imperil repayment owed to sovereign bondholders. Yet legal remedies for the protection of sovereign creditors are generally ineffective, largely because sovereign debt litigation in national courts runs into the constraint of sovereign immunity from enforcement, coupled with a limited pool of attachable assets abroad. The move to arbitration would have the effect of bringing investment treaty arbitration and international financial law much closer together.

"Holdout litigation" — where a majority of creditors accepts the debt restructuring but a minority chooses to sue for full repayment-is a particular concern in sovereign debt restructurings. ${ }^{12}$ Successful holdout litigation undermines participation by otherwise cooperative creditors; the country's inability to bind all creditors threatens to unravel the debt restructuring as a whole. If recent financial crises are any guide, such litigation is on the rise. One reason is the move toward restricted sovereign immunity in London and $\mathrm{New}$ York, with the issuance and restructuring of sovereign bonds being classified as commercial transactions. ${ }^{13}$

To facilitate future sovereign debt restructurings, the international community advocated the inclusion of contractual restructuring clauses in sovereign bonds. ${ }^{14}$ The purpose of these collective action clauses (CACs) is to alleviate the collective action problem that arises when a country has numerous dispersed creditors with divergent interests-as happens with sovereign bonds, which are regularly traded on financial markets. The shift from bank lending to sovereign bonds over the last two decades has, in this context, exacerbated the collective action problem. ${ }^{15}$ When syndicates of commercial banks dominated sovereign lending, collective restructuring negotiations took place whenever a sovereign faced payment difficulties. In that setting, holdout litigation was not a major concern.

literature for over two hundred years. GIULIO DIENA, IL FALLIMENTO DEGLI STATI E IL DIRITTO INTERNAZIONALE (1898), is an early noteworthy contribution; Kenneth Rogoff \& Jeromin Zettelmeyer, Bankruptcy Procedures for Sovereigns: A History of Ideas, 1976-2001, 49 IMF STAFF PAPERS 470 (2002), surveys a wide range of proposals.

${ }^{12}$ Creditors who take part in the restructuring are referred to as participating creditors, and the others as nonparticipating, or holdout, creditors.

${ }^{13}$ In Republic of Argentina v. Weltover, Inc., 504 U.S. 607 (1992), the U.S. Supreme Court held that the issuance of sovereign bonds was "commercial activity" under the Foreign Sovereign Immunities Act of 1976. Even a suspension of payments for the purposes of stabilizing Argentina's economy was "commercial activity," as this governmental measure was connected to the issuance of the bonds. In Borri v. Argentina, the Italian Supreme Court recently reached the opposite conclusion. The Court found that a default amounted to a sovereign act and was thus covered by immunity. Cass., sez. un., 27 May 2005, n.11225, 88 RIVISTA DI DIRITTO INTERNAZIONALE 856 (2005); see Annamaria Viterbo, Sull'immunità dalla giurisdizione della Repubblica Argentina nel caso dei cd. Tangobond-Nota a Cass. Sezioni Unite n. 11225/2005, in 2005 RESPONSABILITÀ CIVILE E PREVIDENZA 1025 (2005).

${ }^{14}$ The International Monetary Fund originally favored the treaty-based SDRM to deal with unsustainable debt burdens, KRUEGER, supra note 11. For a good overview and examples of colletive action clauses, see International Monetary Fund, The Design and Effectiveness of Collective Action Clauses (2002), at< http://www.imf. $\mathrm{org} / \mathrm{external} / \mathrm{np} / \mathrm{psi} / 2002 / \mathrm{eng} / 060602$ htm $>$. The original impetus came from an influential Group of Ten report, The Resolution of Sovereign Liquidity Crises: A Report to the Ministers and Governors Prepared Under the Auspices of the Deputies (1996), at <http://www.bis.org/publ/gten03.pdf $>$, followed by the group's recommendation for implementation in the Report of the G10 Working Group on Contractual Clauses (2002), at $<$ http://europa.eu.int/comm/economy_finance/publications/efc/gten08en.pdf $>$.

15 On the collective action problem arising in sovereign debt crises, see Sean Hagan, Designing a Legal Framework to Restructure Sovereign Debt, 36 GEO. J. INT'L L. 299 (2005). 
At the beginning of 2005, Argentina restructured its external debt following its 2001-02 debt crisis. ${ }^{16}$ The country used a variety of incentives to encourage participation in the bond exchange. ${ }^{17}$ In February 2005, the Argentine Congress passed Ley 26017, which prohibited a reopening of the exchange and any settlement with nonparticipating bondholders. ${ }^{18}$ After approval by the U.S. Securities and Exchange Commission and unsuccessful challenges to the exchange, only 76 percent of bondholders accepted the bond exchange. ${ }^{19}$ Participating bondholders received about 25-29 percent of their bonds' face value. ${ }^{20}$ Holders of roughly U.S.\$20 billion in bonds did not tender in the exchange. Some nonparticipating bondholders brought suit in national courts ${ }^{21}$ but have not succeeded in enforcing the resulting judgments.

In past sovereign debt crises, holdout litigation was limited to national courts ${ }^{22}$ — a situation that could soon change. ICSID could become the new venue of choice for nonparticipating sovereign creditors. $^{23}$ In September 2006, 170,000 Italian bondholders initiated the first ICSID arbitration on sovereign bonds, requesting close to U.S.\$5.5 billion in compensation from Argentina. ${ }^{24}$ This arbitration is coordinated by the Global Committee of Argentina

16 The 2005 bond exchange was preceded by a voluntary "megaswap" in 2001, a domestic restructuring in November 2001, and the March 2002 conversion of all dollar liabilities into pesos. STURZENEGGER \& ZETTELMEYER, supra note 7, at 165-201, provides a detailed overview of Argentina's default and its aftermath. For details, see Prospectus Supplement (of Jan. 10, 2005, to Prospectus [of the Republic of Argentina] dated Dec. 27, 2004), Reg. No. 333-117111, at < http://www.sec.gov>.

${ }^{17}$ Incentives for participation included a GDP warrant that promised additional payment if Argentina's GDP grew above 3\%; a buyback plan for performing debt (that is, debt instruments held by nonparticipating creditors); and a most-favored-creditor clause to protect those creditors who tendered against subsequent better treatment of holdout creditors. STURZENEGGER \& ZETTELMEYER, supra note 7, at 188-96.

${ }^{18}$ Law No. 26017, Feb. 10, 2005, at<http://www.infoleg.gov.ar/infolegInternet/verNorma.do?id=103619>. The law was designed to reduce the incentives for holding out. Article 2 provides that the Argentine executive cannot reopen its exchange offer. Article 3 prohibits judicial or out-of-court settlement on the bonds. Article 4 calls upon the executive to delist the bonds in Argentina and abroad.

${ }^{19}$ In Argentina's restructuring, participation was unusually low. Participation usually exceeds 90 percent.

${ }^{20}$ Federico Sturzenegger \& Jeromin Zettelmeyer, Haircuts: Estimating Investor Losses in Sovereign Debt Restructurings, 1998-2005 (IMF Working Paper No. 05/137, 2005) (presenting detailed estimates of haircuts of different bonds).

${ }^{21}$ Nonparticipating bondholders initiated dozens of lawsuits in New York, and in excess of a hundred in Germany and Italian courts. STURZENEGGER \& ZETTELMEYER, supra note 7, at 201.

${ }^{22}$ Allied Bank Int'l v. Banco Credito Agricola de Cartago, 757 F.2d 516 (2d Cir. 1985) (finding in favor of a holdout bank after a rehearing where the U.S. government intervened as amicus curiae); see Pravin Bankers Assocs., Ltd. v. Banco Popular del Peru, 109 F.3d 850, 854 (2d Cir. 1997); Elliott Associates, L.P. v. Banco de la Nacion, 12 F.Supp.2d 328 (S.D.N.Y. 1998). For Germany, see, for example, Amtsgericht Frankfurt am Main, 32 C $1511 /$ 02, May 6, 2003, at <http://web2.justiz.hessen.de/migration/rechtsp.nsf/suche?Openform > (see comment by August Reinisch, Wirksamkeit eines Arrestbefehls gegen den Staat Argentinien, 58 JURISTENZEITUNG 1013 (2003)).

${ }^{23}$ For a brief introduction to ICSID arbitration, see LUCY REED, JAN PAULSSON, \& NIGEL BLACKABY, GUIDE TO ICSID ARBITRATION 107-09 (2004).

${ }^{24}$ See supra note 1; Task Force Argentina Press Release, Bond argentini: Tfa, depositato all'Icsid il ricorso per oltre 170.000 risparmiatori (Sept. 18, 2006), at < http://www.tfargentina.it/download/TFA-Comunicatostampa180906. pdf >; Bonistas italianos recurren ante el Ciadi, LA NACIÓN (Arg.), Sept. 18, 2006, available at <http://www. lanacion.com.ar/economia/nota.asp?nota_id=841564>; Benedict Mander, New Tack on Argentina Debt: Italian Retail Investors Are Making a Compensation Case to the World Bank, FIN. TIMES, Sept. 29, 2006, at 43. In March 2007, a second group of Italian bondholders requested ICSID arbitration. See Alemanni v. Argentine Republic, ICSID Case No. ARB/07/8 (registered Mar. 27, 2007). U.S. bondholders might follow suit. The American Task Force Argentina is one vocal creditor group. See Hal S. Scott, Sovereign Debt Default: Cry for the United States, Not Argentina (Washington Legal Foundation, Working Paper Series No. 140, 2006), at < http://atfa.org/resources/ scott_wp.pdf $>$. After Russia's 1998 default, a bondholder committee initiated ICSID arbitration. The case was reportedly settled. See Wälde, supra note 2, at 402 n.44. Bookerv. Guyana is a settled ICSID arbitration that involved a holdout creditor. Guyana had defaulted on promissory notes held by Booker, a British company with stakes in 
Bondholders (GCAB), one of the main bondholder organizations formed after Argentina's default. ${ }^{25}$

Why is ICSID arbitration attractive to bondholders? GCAB has suggested that ICSID represents "a more efficient litigation path" ${ }^{26}$ since ICSID awards possess a number of potential advantages over national court judgments. First, ICSID awards increase the chance of recovery since countries can be expected to pay ICSID awards. ${ }^{27}$ Second, their recognition, unlike national court judgments, is not subject to substantive review. They are equivalent to final judgments in all ICSID member states. $^{28}$ Third, even if neither of these two advantages actually obtains, a favorable award could be a valuable bargaining chip for bondholders. It must be mentioned, however, that the enforcement of ICSID awards might still run into the barrier of immunity from execution. ${ }^{29}$

Would arbitration on public debt open a Pandora's box? In 1898, a Mexican-U.S. mixed commission alluded to the implications that arbitrating sovereign bonds would have for borrowing governments and capital markets. That commission found that the "disturbance which would ensue in the administration, credit, and relation of modern nations, if the claims on account of the public debt, such as those involved in this case, were made the matter of international claims, has long been understood." 30

ICSID arbitration on sovereign debt instruments ${ }^{31}$ could fundamentally alter the dynamics of future sovereign debt restructurings. Bondholders might be able to obtain compensation, even though the contractually prescribed majority accepted the restructuring. ICSID arbitration could blow a hole in the international community's collective action policy. Consolidation of bondholder claims to include those of different nationalities, while facilitating bondholder coordination, could magnify this effect. ${ }^{32}$ Such bundling is also likely to shift bargaining power to nonparticipating creditors as a group, and away from participating bondholders and the country in default. ${ }^{33}$

the Guyana sugar industry, in 1989 and attempted several times to settle the debt under the Paris Club. Booker argued that nationalization debts were covered neither by the Paris Club nor the HIPC Initiative. The case was settled in 2002, prior to a decision on jurisdiction. This settlement agreement is not public. Booker PLC v. Co-operative Republic of Guyana, ICSID Case No. ARB/01/9) (discontinuance of proceeding pursuant to Arbitration Rule 43(1) on October 11, 2003).

${ }^{25}$ Such private organizations for coordinating bondholders have a long history. PAOLO MAURO, NATHAN SUSSMAN, \& YISHAY YAFEH, EMERGING MARKETS AND FINANCIAL GLOBALIZATION: SOVEREIGN BOND SPREADS IN 1870-1913 AND TODAY 134-174 (2006), provides an excellent introduction.

${ }^{26}$ Memorandum from Owen Pell to the Global Committee of Argentina Bondholders (Feb. 15, 2005) ("Recent Argentine Legislation and Bondholder Remedies"), at < http://www.gcab.org/images/GCAB___ICSID_Position_ Paper_2-15-05.pdf $>$ [hereinafter GCAB memorandum].

27 So far, every ICSID award has been paid. "At ICSID, there's never been a case in which a sovereign has failed to pay an award." Carolyn Kolker, When Nations Go Bust, 25 AM. LAW. 90, 92 (2003) (quoting Ko-Yung Tung, ICSID's secretary-general from 2000 to 2005). However, future willingness to pay could suffer insofar as ICSID awards are based on tenuous grounds.

28 See Convention on the Settlement of Investment Disputes Between States and Nationals of Other States, Mar. 18, 1965, Art. 54, 17 UST 1270, 575 UNTS 159 [hereinafter ICSID Convention].

${ }^{29}$ Id., Art. 55.

30 JOHN BASSETT MOORE, HistOrY AND DigEST OF THE INTERNATIONAL ARBITRATIONS TO WHICH THE United STATES HAS BEen A PARTY 3616 (1898) (quoting Du Pont de Nemours \& Co. v. Mexico (1868)).

31 The term "debt instruments" refers to various borrowing transactions, including syndicated loans, sovereign bonds, treasury notes, promissory notes, and credit facilities.

32 The obstacles to such bundling — in particular, across nationalities_ seem formidable. Bundling of bondholder claims is examined in more detail in part III, below.

${ }^{33}$ One way in which this effect could operate is through reduced costs of enforcement. 
The multilateral Convention on the Settlement of Investment Disputes Between States and Nationals of Other States ${ }^{34}$ (ICSID Convention) created ICSID as an autonomous international organization with close links to the World Bank Group. ${ }^{35}$ ICSID’s founding aim was to contribute to a stable and positive investment climate. ${ }^{36}$ Although ICSID awards do not possess the force of precedent, ICSID arbitral tribunals frequently rely on past awards. Three arbitrators typically sit on ICSID tribunals. ${ }^{37}$ Grounds for contesting awards are extremely limited. ${ }^{38}$ It may fairly be said that the awards contribute to the corpus of international investment law. ICSID arbitral awards will therefore be a central part of this article.

Bilateral investment treaties (BITs) grant foreign investors certain treaty protections as to the behavior of the host country. ${ }^{39}$ For example, the host country commits not to expropriate "investments." 40 In the early days of investment treaty arbitration, individually negotiated arbitration clauses in investment agreements between investors and host countries ${ }^{41}$ explicitly expressed consent to arbitration. By contrast, BITs provide blanket consent, avoiding the need for consent in each contract. ${ }^{42}$ Under many BITs, investors enjoy direct access to ICSID arbitration for alleged breaches of treatment obligations. ${ }^{43}$ Other BITs provide for arbitration under the rules promulgated by the UN Commission on International Trade Law (UNCITRAL)

${ }^{34}$ Mar. 18, 1965, 17 UST 1270, 575 UNTS 159. For an excellent introduction, see REED ET AL., supra note 23, at $1-9$.

${ }^{35}$ See the ICSID Web site at < www.worldbank.org/icsid/>. In the past, the World Bank had at times exercised good offices over investment disputes. LOWENFELD, supra note 7, at 456-61, provides a brief historical sketch of the Convention.

36 The Convention is "designed to facilitate the settlement of disputes between States and foreign investors," with a view to "stimulating a larger flow of private international capital into those countries which wish to attract it." Executive Directors of the International Bank for Reconstruction and Development, Report of the Executive Directors on the Convention on the Settlement of Investment Disputes Between States and Nationals of Other States, para. 9 (Mar. 18, 1965), at <http://worldbank.int/icsid/basicdoc/basicdoc.htm> [hereinafter ICSID Report].

37 The investor and the host country select one each. The president is appointed jointly by the parties or, if they fail to agree, by the chairman of ICSID's Administrative Council.

38 The ICSID Convention provides only for an annulment procedure. Divergent interpretations by ICSID tribunals of factually similiar cases have stoked a debate whether to establish an ICSID appellate body along the lines of the World Trade Organization. ICSID Secretariat, Possible Improvements of the Framework for ICSID Arbitration, paras. 20-23 (Oct. 26, 2004), at< http://www.worldbank.org/icsid/highlights/improve-arb.pdf>; CHRISTIAN J. TAMS, AN APPEALING OPTION? THE DEBATE ABOUT AN ICSID APPELLATE STRUCTURE (2006) (both envisaging a single mechanism for appeal). A good, recent example of how awards may diverge can be found in $L G \& E$ Energy Corp. v. Argentine Republic, ICSID Case No. ARB/02/1, Liability (Oct. 3, 2006), 46 ILM 40 (2007) (including an introductory note by August Reinisch), versus CMS Gas Transmission Co. v. Argentine Republic, Award, ICSID Case No. ARB/01/08, Award (May 12, 2005), 44 ILM 1205 (2005) [hereinafter CMS Award]. On the divergent approach to necessity in the two cases, see Stephan Schill, International Investment Law and the Host State's Power to Handle Economic Crises, 24 J. INT'L ARB. 211 (2007), and Michael Waibel, Two Worlds of Necessity in ICSID Arbitration: CMS vs. LG\&E, 20 LEIDEN J. INT'L L. 637 (2007).

${ }^{39}$ Over the last decades, the number of BITs exploded. Today, more than 2500 BITs are in force. For a detailed study, see RUDOLF DOLZER \& MARGRETE STEVENS, BILATERAL INVESTMENT TREATIES (1995). REED ET AL., supra note 23 , at 38-62, provides a good introduction to BITs.

40 These behavioral standards in BITs may or may not be higher than what customary international investment law requires. LOWENFELD, supra note 7, at 473-88, sets out typical substantive rules contained in BITs.

41 The host country is the country in whose territory an investment is made.

42 This type of arrangement is known as arbitration without privity, a term coined by Jan Paulsson, Arbitration Without Privity, 10 ICSID REV. 232-56 (1995); see also DOLZER \& STEVENS, supra note 39, at 131-36; Walid Ben Hamida, L'arbitrage transnational unilateral (2003) (unpublished Ph.D. dissertation, Université Panthéon-Assas, Paris II) (on file with author).

${ }^{43}$ Under the new investment treaty regime of the ICSID Convention, the investor-claimant may take the host country directly to arbitration, without the exercise of diplomatic protection. 
or International Chamber of Commerce. ${ }^{44}$ Dispute settlement is thus removed from the exclusive jurisdiction of host countries. In this article, the focus will be on the Argentina's BITs with Germany, Italy, and the United States. ${ }^{45}$

Due to the private interests at the heart of the investment disputes that ICSID tribunals address, they apply a hybrid of international and municipal law. ${ }^{46}$ Treaty and contractual claims operate on separate planes. Municipal, not international, law governs whether, where, and how sovereign bondholders may bring contractual causes of action. BITs bring contractual claims under the protective umbrella of international law, which could give rise to causes of action under treaties. Such breaches of treatment obligations are qualitatively different from contractual breaches, which are neither necessary nor sufficient for treaty violations. ${ }^{47}$ Default on sovereign bonds alone does not trigger state responsibility.

Part I explores whether sovereign bonds are "investments" within the jurisdictional scope of the ICSID Convention. Article 25 limits ICSID jurisdiction to "legal dispute[s] arising directly out of an investment." ICSID subject matter jurisdiction requires a double review. Sovereign bonds need to fall into Article 25's objective core of "investment" and be covered by the relevant BIT. I contend that sovereign bonds are commercial transactions and thus outside this objective core. ICSID holdout arbitration might therefore fail at the initial, jurisdictional stage.

Part II evaluates jurisdictional conflicts arising from ICSID arbitration on sovereign bonds. Current international investment law has few rules to resolve such conflicts. The focus is on whether the host state has consented to ICSID jurisdiction based on the combined terms of the BIT and the sovereign bond. I argue that exclusive domestic jurisdiction and CACs in sovereign bonds governed by municipal law could bar recourse to ICSID. Arbitration through ICSID, not contemplated when the contract was concluded as a whole, threatens to unravel the unity of the bond's contractual bargain.

Part III turns to state responsibility on sovereign bonds. I examine four treatment standards that are especially attractive to holders of sovereign debt: (1) expropriation, (2) fair and equitable treatment, (3) national treatment, and (4) most-favored-nation (MFN) treatment. ${ }^{48} \mathrm{I}$ argue that failure to pay a sovereign bond does not engage the state's international responsibility, even if it constitutes a contractual default under the bond. Coercive sovereign debt restructurings, by contrast, could give rise to international liability.

Part IV considers how peculiar characteristics of sovereign bonds traded on secondary markets affect the fair market value of sovereign bonds. I explain why compensation to bondholders for frustrating their legally protected expectations might lie substantially below the bond's

\footnotetext{
${ }^{44}$ These two sets of rules are among the most common in international commercial arbitration. The UNCITRAL Arbitration Rules were adopted April 28, 1976. The ICC Rules on Arbitration (last updated in 1998) allow for arbitration before the International Court of Arbitration in Paris and for ad hoc arbitration.

${ }^{45}$ U.S., German, and Italian nationals are the largest groups of nonparticipating bondholders. These three BITs are consequently the most relevant for holdout arbitration against Argentina.

${ }^{46}$ Christoph Schreuer, International and Domestic Law in Investment Disputes, 1 AUSTRIAN REV. INT'L \& EUR. L. 89 (1996).

47 "[T] he widely accepted principle . . . under general international law, [is that] a violation of a contract entered into by a State with an investor of another State, is not, by itself, a violation of international law." Société Générale de Surveillance S.A. v. Pakistan, ICSID Case No. ARB/01/13, Objections to Jurisdiction, para. 167 (Aug. 6, 2003) [hereinafter SGS-Pakistan Jurisdiction Decision], 18 ICSID REV. 301 (2003), 8 ICSID REP. 406 (2005), 42 ILM 1290 (2003).

48 See GCAB memorandum, supra note 26, at 3-4 (highlighting expropriation as a promising treatment standard). Countries in default often treat national and foreign creditors differently, which could give rise to claims based on national and most-favored-nation (MFN) treatment. See infra text accompanying notes 158-75.
} 
face value. My conclusions highlight how ICSID arbitration would increase incentives for all creditors to hold out for full repayment. This development could dramatically reshape future sovereign debt restructurings.

\section{ICSID JURISDICTION OVER DEBT INSTRUMENTS}

Article 25 of the ICSID Convention sets up jurisdiction ratione materiae for "any legal dispute arising directly out of an investment." ICSID does not enjoy jurisdiction over ordinary commercial transactions. Since the ICSID Convention does not define "investment," jurisdiction has always been fertile territory for argument. In the early days of ICSID, the view was widespread, however, that by including an ICSID arbitration clause in the contract, the parties implicitly concurred that the object of the dispute was indeed an "investment" under Article $25 .{ }^{49}$

The rise of BITs placed consent at one remove from the alleged investment. A double review for ICSID subject matter jurisdiction became the norm. ${ }^{50}$ Even if a cross-border transaction falls under the BIT's investment definition, it may nonetheless be outside ICSID jurisdiction because the transaction fails to satisfy Article 25. Conceptually, ICSID subject matter jurisdiction is thus evaluated in a two-step test: first, whether the dispute arises out of an investment according to Article 25 of the Convention, rather than being an ordinary commercial transaction, and second, whether the dispute relates to an investment as defined in the BIT.

Subject matter jurisdiction under Article 25 is distinct from consent in the BIT. Parties to a BIT cannot define the multilateral meaning of "investment" in the Convention. Access to ICSID dispute settlement cases is thus conditioned on Article 25's "outer limits." ${ }^{1}$ In all cases, the transaction needs to fall within Article 25's "objective core." Conversely, BIT consent could be narrower than Article 25, which covers a broad set of transactions.

There is strong authority for a two-step evaluation of jurisdiction. Aaron Broches, former general counsel of the World Bank and spiritus rector of the Convention, recognized that the absence of a definition of "investment" does not translate into unlimited jurisdiction: "The fundamental condition is consent . . . But consent is not enough. The Centre is an institution

\footnotetext{
${ }^{49}$ Prior to the proliferation of BITs, in cases where the underlying contract itself gave consent to ICSID arbitration, the Convention's definition of investment was a less salient concern.

${ }^{50}$ CHRISTOPH H. SCHREUER, THE ICSID CONVENTION: A COMMENTARY, paras. 80, 89 (2001). Since this conceptual decomposition is relevant only on the margin of subject matter jurisdiction, decisions on jurisdiction tend to gloss over these two steps. Joy Mining Machinery Ltd. v. Arab Republic of Egypt, Jurisdiction, ICSID Case No. ARB/03/11, paras. 43, 48, (Aug. 6, 2004) [hereinafter Joy Mining Jurisdiction Award], has an explicit decomposition into two steps. SGS Sociêté Générale de Surveillance S.A. v. Republic of the Philippines, ICSID Case No. ARB/ 02/6, Objections to Jurisdiction, para. 154 (Jan. 29, 2004) [hereinafter SGS-Philippines Jurisdiction Award], further supports this position: "The jurisdiction of the Tribunal is determined by the combination of the BIT and the ICSID Convention." See also Mitchell v. Democratic Republic of Congo, ICSID Case No. ARB/99/7, Application for Annulment (Nov. 1, 2006), at <http://www.iisd.org/pdf/2006/itn_icsid_v_drc.pdf $>$ [hereinafter Mitchell Annulment Application] ("the special and privileged arrangements established by the Washington Convention can be applied only to the type of investment which the Contracting States to that Convention envisaged" (para. 31), and "the Washington Convention has supremacy over an agreement between the parties or a BIT" (para. 25)); Malaysian Historical Salvors SDN, BHD v. Government of Malaysia, ICSID Case No. ARB/05/10, Jurisdiction, paras. 43, 54-55 (May 17, 2007) [hereinafter Historical Salvors Jurisdiction Award] (referring to the "doublebarrelled test" for jurisdiction, the first leg of which is "the objective criterion of an 'investment").

${ }^{51}$ Aron Broches, The Convention on the Settlement of Investment Disputes Between States and Nationals of Other States, 132 RECUEIL DES COURS 330, 330 (1972 II) uses this term.
} 
of limited jurisdiction, limited . . by the nature of the dispute." 52 In the words of Antonio Parra, ICSID jurisdiction requires a "double review of the criteria for coverage of the parties and the dispute, first from the viewpoints of the ICSID Convention and then from the viewpoint of the investment treaty." ${ }^{53}$ The requirement of an investment in Article 25 may thus not automatically be merged into consent to jurisdiction. ${ }^{54}$

As the next section shows, case law fails to reveal a strong basis for ICSID jurisdiction over bonds.

\section{Sovereign Bonds as "Investment" Under Article 25 of the ICSID Convention}

What exactly are sovereign bonds? Defining their nature and characteristics is the natural first step in determining ICSID jurisdiction. Sovereign bonds are country debt instruments acknowledging indebtedness and promising repayment of principal and interest on an earlier advance of money. ${ }^{55}$

Are sovereign bonds "investments" under Article 25 of the Convention? During negotiations, various attempts at defining that term failed; this lack of consensus was the primary reason for the Convention's silence on the definition of "investment." George Delaume had also counseled against including a definition in the Convention, as it would inevitably lead to "jurisdictional wrangles." 56

Since in ordinary usage, "investment" has various meanings, ${ }^{57}$ a textual interpretation of the ICSID Convention alone fails to reveal whether debt instruments and sovereign bonds fall under Article 25's scope. ${ }^{58}$ In finance, investments include all purchases of financial assets. In economics, investment is a component of GDP and stands for gross capital formation. This definition excludes purchases of financial instruments by households. The meaning of investment in international law is also blurry. ${ }^{59}$ Divergent BIT definitions of investment further

\footnotetext{
${ }^{52} I d$. at 351-52.

${ }^{53}$ Antonio Parra, The Institutions of ICSID Arbitration Proceedings, 20 NEWS FROM ICSID 13 (2003), available
} at < http://worldbank.com/icsid/news/news_20-2.pdf>. Parra was deputy secretary-general of ICSID from 1999 to 2005 and on ICSID's staff for seventeen years.

${ }^{54}$ A. Broches, The Convention on the Settlement of Investment Disputes: Some Observations on Jurisdiction, 5 COLUM. J. TRANSNAT'L L. 263, 268 (1966) (presenting the contrary view "that the requirement that the dispute must have arisen out of an 'investment' may be merged into the requirement of consent to jurisdiction”).

${ }^{55}$ Debentures, promissory notes, and certificates of indebtedness display similar features. Historically, a bond is a "document written and sealed containing a confession of a debt." FREDERICK POLLOCK \& FREDERIC WILLIAM MAITLAND, THE HISTORY OF ENGLISH LAW BEFORE THE TIME OF EDWARD I, at 207 (1899). Borchard defines sovereign bonds as the "principal document containing the terms of the contractual relationship between the debtor government and the individual lender . . . issued by the bank in accordance with the loan agreement or directly by the government pursuant to the loan prospectus. It evidences the promise by the borrower to pay the agreed interest on the loan, the principal at maturity, and to amortize the issue in a specified manner." EDWIN BORCHARD \& WILLIAM H. WYNNE, STATE INSOLVENCY AND FOREIGN BONDHOLDERS 23 (1951).

562 CONVENTION ON THE SETTLEMENT OF INVESTMENT DISPUTES BETWEEN STATES AND NATIONALS OF OTHER STATES: DOCUMENTS CONCERNING THE ORIGIN AND THE FORMULATION OF THE CONVENTION 59 (1968) [hereinafter ICSID HISTORY]. Delaume was an influential legal adviser at the World Bank and later ICSID. See also the justification for this definitional lacuna in ICSID Report, supra note 37, para. 27: "No attempt was made to define the term 'investment' given the essential requirements of consent by the parties .... ." In discussing the legislative history, Schreuer notes that the preceding assertion is historically incorrect: "There were a number of attempts but they all failed.” SCHREUER, supra note 50, para. 86. See generally id., paras. 81-88.

57 See Vienna Convention on the Law of Treaties, May 23, 1969, Art. 31, 1155 UNTS 331. The Oxford English Dictionary defines "investment" as "conversion of money or circulating capital into some species of property from which an income or profit is expected to be derived in the ordinary course of trade or business."

58 SCHREUER, supra note 50, para 85.

59 The evolution of, and disagreements concerning, the term "investment" in international law are surveyed by M. SORNARAJAH, THE INTERNATIONAL LAW ON FOREIGN INVESTMENT 9-18 (2004); see also id. at 304-305. 
illustrate the absence of a generally accepted meaning. ${ }^{60}$ During the ICSID Convention negotiations, delegates offered varying views on the inclusion of bonds and loans; ${ }^{61}$ a historical interpretation of the ICSID Convention thus also yields no clear result.

Given this textual and historical ambiguity, it is useful to look at how ICSID tribunals have dealt with debt instruments so far. In particular, the two main cases dealing with such instruments have both held that they amount to investments. Pre-ICSID Convention cases, while rich in instructive examples, ${ }^{62}$ shed only limited light on the theoretical foundations of bondholder claims under ICSID.

In Fedax $v$. Venezuela the tribunal regarded promissory notes issued by Venezuela and assigned by another company to Fedax as an "investment": "Since promissory notes are evidence of a loan and a rather typical financial and credit instrument, there is nothing to prevent their purchase from qualifying as an investment under the [ICSID] Convention in the circumstances of a particular case such as this." 63 The tribunal explained that promissory notes are not like "volatile capital"; they satisfy the basic features of an investment- that is, "a certain duration, a certain regularity for profit and return, assumption of risk, a substantial commitment, and a significance for the host State's development." 64

A crucial point at the jurisdictional stage was that the promissory notes contributed substantially to Venezuela's treasury. The Fedax tribunal reasoned that the

promissory notes were issued by the Republic of Venezuela under the terms of the Law on Public Credit ... , which specifically governs public credit operations aimed at raising funds and resources "to undertake productive works, attend to the needs of national interest and cover transitory needs of the treasury." It is quite apparent that the transactions involved in this case are not ordinary commercial transactions and indeed involve a fundamental public interest. ${ }^{65}$

The Fedax tribunal's analysis stopped at this critical juncture. The tribunal overlooked the distinction that economic transactions may well "involve a fundamental public interest" yet fail to satisfy Article 25's requirements for an "investment." The mere presence of a "fundamental public interest" does not transform a commercial transaction into an "investment." Importing such a public interest criterion of overarching scope into the qualification of "investment" lacks

\footnotetext{
${ }^{60}$ The BIT definitions serve merely as illustrations. The meaning of "investment" under the multilateral ICSID Convention cannot be inferred from BITs.

${ }^{61}$ Burundi emphasized that money lent by a foreign company to a state could not be regarded as an investment. 2 ICSID HISTORY, supra note 56, at 261. Austria submitted that "public loans or bonds should not be included." $I d$. at 709. The Australian delegate, by contrast, highlighted that the draft convention seemed to include not only cases where the investor acquired "tangible assets in the host country," but also "the borrowing of cash . . . from foreign private investors.” Id. at 474.

${ }^{62}$ It is beyond the scope of this article to survey the numerous decisions by international courts and by mixed commissions on sovereign bonds. In an unpublished Ph.D. dissertation (Université de Gèneve, 2005), The Legal Practice of the Recovery of State External Debts, at 104-38 (on file with author), Gustavo Adolfo Olivares Marcos provides a representative survey of international awards and judgments on sovereign external debt. GERMAIN WATRIN, ESSAI DE CONSTRUCTION D'UN CONTENTIEUX INTERNATIONAL DES DETTES PUBLIQUES (1929) covers older case law. These decisions provide valuable insight into legal and policy considerations at stake in arbitrating sovereign bonds.

${ }^{63}$ Fedax N.V. v. Republic of Venezuela, ICSID Case No. ARB/96/3, Objections to Jurisdiction, para. 29 (July 11, 1997), 5 ICSID REP. 186 (2002), 37 ILM 1378 (1998) [hereinafter Fedax Jurisdiction Decision].

${ }^{64}$ Id., para 43. These are Schreuer's typical requirements of jurisdiction turned normative. See infra note 80 and accompanying text.

${ }^{65}$ Fedax Jurisdiction Decision, supra note 63, para. 42.
} 
a sound basis in the ICSID Convention. Almost every legitimate governmental transaction satisfies Fedax's erroneous public interest test. By the same token, the set of ordinary commercial transactions under Fedax is virtually empty.

In CSOB v. Slovak Republic, the second important ICSID case on debt instruments, a consolidation agreement between the bank CSOB and the Czech and Slovak Ministries of Finance provided for the assignment of certain nonreceivables to a specially constituted Slovak collection company that was to be financed by a loan. ${ }^{66}$ Slovakia undertook to make good the collection company's losses, enabling repayment of the loan to CSOB. The tribunal noted that the term "directly" in Article 25(1) should not be interpreted narrowly. The loan was held to constitute an "investment" even though the claim was based on an obligation that, standing alone, did not qualify as an investment.

Which generalizations are possible from this case law? So far, ICSID tribunals have liberally accepted jurisdiction over debt instruments despite Article 25's ambiguity. ${ }^{67}$ Only a few ICSID tribunals have declined jurisdiction for failure of the "investment" requirement; 68 "no jurisdiction" is a rare occurrence in ICSID arbitration. It would be wrong to infer from Fedax and CSOB, however, that ICSID has jurisdiction over debt instruments. Both cases mistakenly ascribe primary importance to the purpose of the transaction (which, under Article 25, ICSID tribunals are bound to take into account but which should not therefore be taken as determinative).

Fedax cannot serve as a precedent for ICSID arbitration on sovereign bonds governed by private foreign law. ${ }^{69}$ Sovereign bonds are commercial transactions that are usually governed by the municipal law of a major financial center; immunity from jurisdiction is waived. ${ }^{70}$ Countries issuing such debt on international capital markets place themselves in the position of arm's-length contract parties. The promissory notes in Fedax are fundamentally distinct from modern sovereign bonds, however; they were issued under Venezuela's own law and subject

${ }^{66}$ Ceskoslovenska Obchodni Banka, A.S. v. Slovak Republic, Objections to Jurisdiction, ICSID Case No. ARB/ 97/4 (May 24, 1999), 14 ICSID REV., 251 (1999) [hereinafter CSOB Jurisdiction Decision]. See also CDC Group PLC v. Republic of the Seychelles, Award, ICSID Case No. ARB/02/14 (Dec. 17, 2003), where the Seychelles had guaranteed loans to a public utility corporation. The case was not based on a BIT, but on a specific arbitration agreement. The Seychelles accepted that the loan and the guarantee constituted an investment under Article 25.

${ }^{67}$ OKO Pankki Oyj v. Republic of Estonia, ICSID Case No. ARB/04/6 (registered Feb. 20, 2004), and I \& I Beheer B.V. v. Bolivarian Republic of Venezuela, ICSID Case No. ARB/05/4 (registered Apr. 6, 2005), are two pending ICSID cases on debt instruments. For a brief description of the former, which concerns a private loan, see Estonia Facing Foreign Banks' Euro 27.5 Million Claim, BALTIC BUS. DAILY, Jan. 4, 2006. For a description of the latter, which revolves around promissory notes issued by a Venezuelan agricultural development bank, see Daphne Eviatar, Oye Como Va: As Venezuelan President Hugo Chavez Takes on Multinationals, the Arbitration Lawyers Are Circling In, AM. LAWYER, Dec. 1, 2005, at 28. I \& I Beheer concerns international debt instruments issued in Zurich under Swiss law.

${ }^{68}$ The Joy Mining Jurisdiction Award, supra note 50, para. 54, declined to qualify a bank guarantee tied to a contract for the provision of mining equipment as "investment." Likewise, the Historical Salvors Jurisdiction Award, supra note 50, paras. 107-46, reached the same conclusion regarding a salvage operation for Chinese porcelain off the Malaysian coast. In Mihaly Int'l Corp. v. Democratic Socialist Republic of Sri Lanka, ICSID Case No. ARB/00/2, Award (Mar. 15, 2002), 41 ILM 867 (2002), the tribunal found that preparatory expenses in the absence of a binding investment contract did not amount to an investment. The ad hoc committee's decision in the Michell Annulment Application, supra note 50, was the first time that an ICSID award was set aside for (among other reasons) want of an investment. In 1985, the ICSID secretariat declined registration of a claim arising out of a contract for the sale of goods in the Asian Express v. Greater Colombo Economic Commission case. See Ibrahim F. I. Shihata \& Antonio R. Parra, The Experience of the International Centre for Settlement of Investment Disputes, 14 ICSID REV. 299, 308 (1999).

69 This restriction is perhaps implicit in the Fedax Jurisdiction Decision, supra note 63, para. 29, when the tribunal noted that sovereign bonds would qualify as "investment," but only in "given circumstances."

70 The nature of the transaction does not change simply because enforcing municipal judgments against a state might prove more difficult than against a private party. 
to the exclusive jurisdiction of Venezuelan courts. Since Venezuela retained important public powers over such debt instruments, they were not commercial transactions.

Even if Fedax and $C S O B$ - with their characterization of promissory notes and loans as "investments" - are considered to be correct, care should be taken not to extrapolate erroneously beyond the particular circumstances of those cases. Other distinguishing features of sovereign bonds relative to loans are that they are easily tradable on the secondary market and that trustees and fiscal agents act as intermediaries. Bondholders are atomized and anonymous. Bonds are bought on the secondary market without formal or other specific relationship with the debtor government. ${ }^{71}$ Bondholders' nationalities might change with every transaction. ${ }^{72}$ For these reasons, ICSID tribunals might treat sovereign bonds differently than loans.

There is some support among commentators for ICSID jurisdiction over debt instruments. Delaume posited that "the characterization of transnational loans as 'investments' has not raised difficulty. ... [F] rom the origin of the Convention [it has been assumed] that longer term loans were included in the concept of "investment" (though this problematic proposition relies on the (rejected) first draft of the Convention). ${ }^{73}$ Prior to Fedax, Schreuer argued that "[i]t would depend on the particular circumstances of the case whether the extension of loans or the purchase of bonds will qualify as investments." 74 This passage no longer appears in his commentary. ${ }^{75}$

Whereas both Fedax and CSOB depend on special considerations, I argue below that both cases were wrongly decided for a more fundamental reason. By brushing over the elements of investment mentioned above, the two tribunals subsumed all portfolio investments ${ }^{76}$ under "investments." Article 25's definition of investment is not infinitively elastic. Sovereign bonds do not display the typical features of an investment. They are ordinary commercial transactions outside ICSID's objective jurisdictional core.

\section{The Objective Core of ICSID Jurisdiction}

"Investment" has a multilateral meaning. ${ }^{77}$ Consent to ICSID arbitration through a BIT does not in itself control. Article 25 of the ICSID Convention purposefully set up a substantive invest-

\footnotetext{
${ }^{71}$ In the secondary market for sovereign debt, loans and bonds are exchanged between buyer and seller, often at substantial discounts from their face value. These discounts reflect the likelihood of eventual repayment. The rise of secondary markets since 1980 has provided incentives to buy below par and pursue litigation for full principal and interest. For an overview of secondary markets and their development, see Philip J. Power, Sovereign Debt: The Rise of the Secondary Market and Its Implications for Future Restructurings, 64 FORDHAM L. REV. 2701, 2715-19 (1996).

72 The Fedax Jurisdiction Decision, supra note 63, para. 40, acknowledges as much: "[T] he identity of the investor will change with every endorsement."

${ }^{73}$ Georges R. Delaume, ICSID and the Transnational Financial Community, 1 ICSID REV. 237, 242 (1986) (footnote omitted). The first draft defined "investment" as "any contribution of money or other asset of economic value for an indefinite period or, if the period is defined, for not less than five years."

${ }^{74}$ Christoph Schreuer, Commentary on the ICSID Convention: Article 25, 11 ICSID REV. 318, 372 (1996). Schreuer is widely regarded as one of the world's foremost authorities on international investment law. His 2001 commentary on the ICSID Convention, supra note 50, is the standard reference work on ICSID.

${ }^{75}$ It is unclear whether Schreuer thereby merely noted the evolution of ICSID case law or approves of ICSID jurisdiction over debt instruments.

${ }^{76}$ To what extent portfolio investment is included in Article 25's notion of investment is controversial. Sacerdoti notes that "[p]ortfolio investment $[\mathrm{s}]$. . . are . . . not excluded as a rule." Giorgio Sacerdoti, Bilateral Treaties and Multilateral Instruments on Investment Protection, 269 RECUEIL DES COURS 251, 307 (1997).

77 In this sense, "the term 'investment' has an objective meaning independent of the parties' disposition." SCHREUER, supra note 50, para. 90. The most comprehensive discussion of the investment requirement as an objective condition is found in the Historical Salvors Jurisdiction Award, supra note 50, paras. 42-146.
} 
ment requirement in the jurisdictional stage. Only genuine investments are protected. The Convention's silence is content neutral. It would be a mistake to regard the "investment" requirement as merely a pro forma jurisdictional requirement. Legitimacy of ICSID arbitral awards depends on respecting this adjudicatory mission, especially since investor-state arbitration often implicates fundamental public interests and substantial claims for compensation.

Maintaining an objective core meaning of "investment" is also crucial for legal certainty. For that reason, ICSID tribunals have refined the notion of investment by elaborating typical characteristics of investments. ${ }^{78 ~ " T y p i c a l " ~ i n ~ t h i s ~ c o n t e x t ~ m e a n s ~ t h a t ~ a ~ l a r g e ~ m a j o r i t y ~ o f ~ " i n v e s t-~}$ ments" display these characteristics. ${ }^{79}$ Schreuer originally introduced five such elements of "investment" under Article 25: (1) significance for the host state's development (2) sufficient duration, (3) risk sharing, (4) regularity of profit and return, and (5) substantial commitment. ${ }^{80}$ His original intent was purely descriptive, yet many ICSID tribunals subsequently gave these elements normative content.

Absence of one typical element is prima facie, but by no means conclusive, evidence against qualification as an investment. The absence of one element or another is not fatal, and it must also be remembered that the elements themselves are often intertwined in any particular investment and need to be analyzed together. It is beyond the scope of this article to trace out these elements in detail. I focus here on the three (of Schreuer's five) typical elements that are particularly relevant for debt instruments and sovereign bonds: significance for the host state's development; duration; and risk sharing. ${ }^{81}$ Beyond Schreuer's original elements, I introduce two more: a territorial link and an association with a commercial undertaking.

Positive impact on development. Schreuer's first typical element is that an investment has some positive impact on development. ${ }^{82}$ The Convention's preamble contains a reference to "the need for international co-operation for economic development and the role of private international investment therein." The traditional canon of interpretation supports construing an undefined term like "investment" in the light of the preamble, the treaty's objective, and purpose. ${ }^{83}$

$C S O B$ illustrates the prevailing purpose-oriented approach to the positive-impact criterion:

78 Typical elements aim to increase legal certainty. See Consorzio Groupement L.E.S.I._DIPENTA v. People’s Democratic Republic of Algeria, ICSID Case No. ARB/03/8, Award, para. 72 (Jan. 10, 2005) [hereinafter L.E.S.I.-DIPENTA Award].

79 The Historical Salvors Jurisdiction Award, supra note 50, referred to the "typical characteristics," versus "jurisdictional," approach, paras. 69-72, while questioning whether the two approaches differ significantly in practice, paras. 105-06. One qualification applies. There are no general limits on how treaties may define "investment." In bilateral relationships, parties are free to define terms as they see fit. UNCITRAL tribunals, for instance, derive their jurisdiction solely from the agreement to arbitrate. ICSID's Additional Facility also does not require an investment dispute. See SCHREUER, supra note 50, paras. 10-14.

${ }^{80} \mathrm{Id}$., para. 122. The leading case is Salini Costruttori S.p.A. v. Kingdom of Morocco, ICSID Case No. ARB/00/4, Jurisdiction (Juy 23, 2001), 6 ICSID REP. 400 (2004), 42 ILM 609 (2003). The Joy Mining Jurisdiction Award, supra note 50, para. 50, also mentions Article 25's objective requirements. The award in Consortium Groupement L.E.S.I.DIPENTA, para. 72, dispenses with elements regulatory of profit and return and positive impact on development, and alters the feature of substantial contribution in a key respect. See infra text accompanying note 88.

${ }^{81}$ Of Schreuer's five typical elements, only duration, significance for the host state's development, and risk sharing are discussed. Regularity of profit and return is unlikely to be contentious for sovereign bonds. The requirement of a substantial contribution might be material for retail bondholders.

${ }^{82}$ SCHREUER, supra note 50, para. 122. See the Historical Salvors Jurisdiction Award, supra note 50, where the tribunal found that the salvage operation lacked the necessary developmental impact, paras. 113-43, and referred to this typical element as the "litmus test," para. 135.

83 The general rules of treaty interpretation can be found in Article 31 of the Vienna Convention, supra note 57. See Camuzzi International S.A. v. Argentine Republic, ICSID Case No. ARB/03/2, Objections to Jurisdiction, para. 
[T] he basic and ultimate goal of the Consolidation Agreement was to ensure a continuing and expanding activity of CSOB in both Republics. This undertaking involved a significant contribution by CSOB to the economic development of the Slovak Republic; . . . [its qualification as an investment within Article 25] is evident from that fact that CSOB's undertakings include the spending or outlays of resources in the Slovak Republic in response to the need for the development of the Republic's banking infrastructure. ${ }^{84}$

The tribunal did not go beyond registering the transaction's abstract purpose: the spending of resources. Fedax similarly relied heavily on the substantial, albeit abstract, contribution of promissory notes to Venezuela's treasury. ${ }^{85}$

The approach of $C S O B$ and Fedax to the positive-impact criterion is too broad to be either reliable or useful. Under Article 25, potential development and abstract financial flows are not enough. ${ }^{86}$ Mirroring the effect doctrine in expropriation, the actual impact of "investments" in the host countries warrants closer attention; ${ }^{87}$ for practical reasons, evaluating the positive impact on development indirectly is the preferred approach. In particular, if a transaction displays duration, risk sharing, and a territorial link (see below), then it is likely to benefit the host country's development. Both Fedax and CSOB, however, brush over these typical features.

LESI v. Algeria, by dispensing with a separate positive-impact criterion, points the way forward. The tribunal reasoned that the impact on development was difficult to establish and was already implicit in the elements of substantial contribution, duration, and risk sharing. ${ }^{88}$ This line of analysis incidentally raises the issue whether claims by individual bondholders could fall short of the "substantial commitment" deemed typical of an investment. Such a requirement could place retail bondholders at a disadvantage compared to institutional investors.

Long-term transfer offinancial resources (duration). A second typical element of an investment is the long-term transfer of financial resources. While the ICSID Convention leaves open the question of duration, ${ }^{89}$ it is widely recognized that ICSID lacks jurisdiction over short-term financial flows. Fedax takes an overly restrictive of such "volatile capital," however, and leaves that term undefined..$^{90}$ Establishing a minimum duration for the investment would enable transactions to be differentiated according to the length of the investor's commitment.

133 (May 11, 2005). A teleological approach to interpreting "investment" can be found in the Historical Salvors Jurisdiction Award, supra note 50, paras. 65-68.

${ }^{84}$ CSOB Jurisdiction Decision, supra note 66, para. 88. See Salini Costruttori, where the tribunal emphasized that the construction of a highway was clearly of public interest and therefore had a positive impact on Morocco's development.

${ }^{85}$ Fedax Jurisdiction Decision, supra note 63, para. 42.

86 To avoid asymmetrical treatment of host state and investor, the actual, present impact in the host country arguably needs to be given equal weight, reflecting the twofold objective of the ICSID Convention: first, to increase investor protection, and second, to ensure that investments perform an essential economic and social service in developing countries.

87 This emphasis would mirror what Dolzer calls a "remarkable tendency to shift the focus of the analysis away from the context and the purpose and focus more heavily on the effects on the owner." Rudolf Dolzer, Indirect Expropriations: New Developments? 11 N.Y.U. ENVTL L.J. 64, 91. The ad hoc committee in the Michell Annulment Application, supra note 50, relied heavily on the positive-impact criterion to deny the presence of an investment. The tribunal's reasoning is ultimately unsatisfactory, however, in that it defeats the very purpose of providing legal certainty (see, in particular, the ambiguous reasoning in paragraph 33).

${ }^{88}$ L.E.S.I.-DIPENTA Award, supra note 78, para. 72 (iv).

89 The Convention's first draft, albeit inconclusive, might offer a starting point "for not less than five years." See Delaume, supra note 73, at 242.

${ }^{90}$ Fedax Jurisdiction Decision, supra note 63, paras. 42-43. 
Speculative purchases of debt instruments might fail the long-term transfer test. Capital might not be committed long enough to fall under Article 25.91 "Speculative" in this context refers not to the riskiness of the bond, but to short-term financial commitments by individual bondholders. ${ }^{92}$ This factor could be applicable, in particular, to purchases on the secondary market. The draftspersons of the ICSID Convention did not conceive of modern secondary markets for sovereign bonds and other debt instruments.

A preliminary question is whether it is sufficient for sovereign bonds to qualify as an investment on issuance. ${ }^{93}$ The answer is no. Article 25 is sometimes taken to indicate that the substantive requirement of an "investment" is separable from the person requesting arbitration. ${ }^{94}$ That is, if the original bond issue qualified as an investment, then a bondholder could bring a claim even if her secondary-market purchase did not itself amount to investment. ${ }^{95}$ As will become clear, however, the correct view is that the transaction conferring ownership interest to the particular individual bondholder must be an "investment."

Case law provides limited support for declining jurisdiction on the basis of short duration. In Olguin v. Paraguay, Paraguay argued without success that "speculative financial investments" were not covered investments. ${ }^{96}$ In Fedax the tribunal rejected Venezuela's argument that subsequent endorsement of promissory notes took away the character of an "investment." In Saluka, the Czech Republic argued, without success, that Nomura was not a bona fide investor, as short-term acquisitions of shares served the sole purpose of disposing of the Czech bank Investicni a Postovni Banka's assets for profit. ${ }^{98}$ In dismissing the argument that a speculative motive could affect its jurisdiction, the Saluka tribunal stated that it

would [not] be correct to interpret Article 1 as excluding from the definition of "investor" those who purchase shares as part of what might be termed bare profit-making or profittaking transactions. Most purchases of shares are made with the hope that, in one way or another, the result will in due course be a degree of profit on the transaction . . . Even if it were possible to know an investor's true motivation in making its investment, nothing in Article 1 makes the investor's motivation part of the definition of an "investment."99

Even Saluka, however, refers to profit expectations "in due course."

Tribunals need not analyze investors' specific motivations. First, as the Saluka tribunal correctly pointed out, such attempts to discover motivations would often be futile. Given that the

${ }^{91}$ Joy Mining Jurisdiction Award, supra note 50, para. 57.

92 The counterargument may be advanced that despite the purchase on the secondary market, the country did receive the original financing. The sovereign bond issuance as a whole could satisfy the typical feature of a long-term commitment.

${ }^{93}$ Many governments today issue dematerialized global bonds that involve a single debt instrument issued to a financial intermediary (depository), which records bondholder interests in a book-entry system.

${ }^{94}$ A separate question concerns that of standing before ICSID. So far, no ICSID award has clarified whether only "investors" enjoy standing. Under the Convention, the term "investor" has no specific meaning. Article 25 contains only a reference to "national of a Contracting State." BITs, by contrast, often limit consent to "investors."

95 The Fedax Jurisdiction Decision, supra note 63, appears to lean in the direction that separate qualification of secondary market transactions as "investments" is not necessary.

${ }^{96}$ Olguín v. Republic of Paraguay, ICSID Case No. ARB/98/5, Award, para. 65 (July 26, 2001), 18 ICSID REV. 160 (2003) [hereinafter Olguín Award].

${ }^{97}$ Fedax Jurisdiction Decision, supra note 63, paras. 38, 40 (noting "the investment itself will remain constant, while the issuer will enjoy a continuous credit benefit until the time the notes become due").

98 Saluka Investments B.V.v. Czech Republic, Partial Award (UNCITRAL Arb. Trib. Mar. 17, 2006), at<http:// www.pca-cpa.org $>$ [hereinafter Saluka Partial Award].

${ }^{9}$ Id., para. 209. 
case was an arbitration under UNCITRAL Rules, however, it is of limited relevance for ICSID arbitration; whereas the sole determinant of jurisdiction under UNCITRAL is the parties' agreement to arbitrate, Article 25 of the Convention deems the long-term transfer of financial resources to be a typical element of investment and consequently an element in determining of jurisdiction.

Short commitment periods are a reliable means of identifying volatile capital. When sovereign bonds are held only for a short time, they fail to meet the jurisdictional requirement of a long-term transfer of financial resources. ${ }^{100}$ Claimants would simply be required to produce documentary proof of continuous bond ownership for a certain period before default. ICSID tribunals ought to establish clear criteria for the required duration. Short commitments could also be taken into account at the merit stage through the quantification of appropriate compensation. ${ }^{101}$

Sharing of commercial risk. A third typical element of an investment is the sharing of commercial risk. This feature is linked to the association with a commercial undertaking, examined below. "Investments" succeed or fail on the merits of the commercial undertaking - the specific commercial purpose to which capital was committed. Host country and investor share the risk of success and failure. Sovereign bonds, by contrast, are mainly tied to the general macroeconomic condition of the issuing country. They finance the general treasury. No commercial risk is shared among the issuing country and the bondholder. The repayment obligation is fixed, unconditional, and not tied to the success of a commercial undertaking or capital project. The bondholder is to be repaid, independent of the ultimate uses to which the host country puts the resources. Repayment is thus isolated from commercial risk.

Despite this independence from commercial risk, sovereign bondholders-like the holders of virtually all other financial instruments_-are exposed to the risk of default. In particular, they face the same default risk as any contractor doing business with the government; repayment depends solely on the uncertain macroeconomic trajectory of the country involved. For instance, supplying office materials to a government, despite the risk of nonpayment, would no doubt qualify as an ordinary commercial transaction, not an "investment." Analogously, although the default risk inherent in bonds has a special quality because of the sovereign nature of the issuer, that does not in itself indicate the presence of the risk sharing typical of investments.

Fedax's interpretation of risk is unduly broad. The tribunal held that "the very existence of a dispute as to the payment of the principal and interest evidences the risk that the holder of the notes has taken." 102 Every unsecured transaction involves the risk of nonperformance. For this reason, mere default risk cannot be a meaningful standard for qualifying transactions as investments. Some sovereign bonds display high default risk. Yet the mere presence of such risk is not enough. Article 25 contemplates an element of risk sharing. In the words of Joy Mining, "Risk there might be indeed, but it is not different from that involved in any commercial contract." 103

${ }^{100}$ A thirty-year government bond held from issuance to maturity will fufill the long-term transfer criterion.

${ }^{101}$ For discussion see infra part IV.

${ }^{102}$ Fedax Jurisdiction Decision, supra note 63, para. 40. Against such a broad conception of risk, see Historical Salvors Jurisdiction Award, supra note 50, para. 112, in which the tribunal noted that the "quality of the assumed risk" mattered.

${ }^{103}$ Joy Mining Jurisdiction Award, supra note 50, para. 57. 
Territorial link ("in the territory of the host country"). Is it necessary for the "investment" to be located in the host country? In contrast to typical foreign investments, sovereign bonds are intangible capital flows. Their situs is thus more difficult to determine. The crucial issue is whether transactions have a positive impact on the host country's development without physical presence in that country's territory. Such a territorial link represents another typical element of investment under Article 25, ${ }^{104}$ which requires that some workers or physical assets be physically present in the host country's territory. Flows of financial capital alone are insufficient. Until recently, case law on Article 25's territorial link was limited. While a historical interpretation of the Convention provides support for a territorial link, ${ }^{105}$ only CSOB mentioned this element, with the tribunal characterizing CSOB "as an investor and the entire process as an investment in the Slovak Republic within the meaning of the Convention."106

LESI $v$. Algeria buttresses this position. In reducing Schreuer's five typical elements of an investment to three, the tribunal adopted a territorial interpretation of substantial contribution. Implicit in this notion of contribution is that the contracting party made a contribution in the country concerned. ${ }^{107}$ As the tribunal explained, this element is not absolute, but at least part of the contribution needs to occur in the territory of the host country: "It is often the case that these investments are made in the country concerned, but that again is not an absolute condition. Nothing prevents investments from being committed, at least in part, from the contractor's home country, as long as they are allocated to the project to be carried out abroad." 108

For debt instruments traded on secondary markets, the territorial link is especially tenuous. Suppose Ruritania's sovereign bonds being traded on the secondary market in Zurich changed hands. With secondary-market purchases, there is typically no flow of even financial resources into the issuing country. ${ }^{109}$ The debtor state receives funds only on issuance of the bonds, at a single time. In general, secondary-market purchases by bondholders lack a territorial link with the host country. For that reason, they are highly unlikely to contribute to the host country's development.

${ }^{104}$ There is a distinction between the territorial link in Article 25 and in BITs - another emanation of the double review. Whether a BIT requires a territorial link to the host country is separate from whether investments under Article 25 are typically limited to those investments "in the territory of the host state." The territorial requirement of BITs is examined below in the text accompanying notes 123-28.

${ }^{105}$ The ICSID Report, supra note 36, paras. 9, 12 (emphasis added), explains that the creation of ICSID was "designed to facilitate the settlement of disputes between States and foreign investors" with a view to "stimulating a larger flow of private international capital into those countries which wish to attract it" and to "stimulate a larger flow of private international investment into territories."

${ }^{106}$ CSOB Jurisdiction Decision, supra note 66, para. 88 (emphasis added).

${ }^{107}$ L.E.S.I.-DIPENTA Award, supra note 78, pt. II.2, para. 13(iv)(a): "[Q]ue le contractant ait effectué un apport dans le pays concerné" ([that] the contracting party has made contributions in the host country) (ICSID's unofficial English translation). A positive impact on development will often be implicit in substantial contribution, duration, and risk sharing, see supra text accompanying note 88.

${ }^{108}$ L.E.S.I.-DIPENTA Award, supra note 78, para. 14(i) (unofficial ICSID translation). The original French reads:

De même est-il fréquent que ces investissements soient effectués dans le pays concerné, mais il ne s'agit pas non plus d'une condition absolue. Rien n'empêche en effet que des investissements soient en partie du moins engagés depuis le pays de résidence du contractant mais en vue et dans le cadre du projet à réaliser à l'étranger. ified.

${ }^{109}$ If the the seller of the bonds held a bank account in the issuing country, this statement would need to be qual- 
Association with a commercial undertaking. A final typical element of an "investment," inherent in Article 25, is the operation of, or a reasonably close association with, a commercial undertaking. ${ }^{110}$ The meaning of investment in international investment case law comprises equity holdings in private or publicly owned entities whose main goal is commercial. Corporate bonds, for instance, are issued by such entities. They are thus associated with a commercial undertaking and would fulfill this typical feature of an investment.

Sovereign bonds are different. The issuing entity is public. Funds raised via sovereign bonds are typically used for general budgetary purposes. There is no related commercial undertaking. The prospective sovereign bondholder does not participate in the elaboration of specific projects, and evaluates the commitment of capital against that background. Neither personnel nor ideas nor production facilities are associated with the bond. Rather, bondholders look solely to the country's creditworthiness.

The contrast between shares and sovereign bonds is instructive. Shares are associated with a commercial undertaking. Yet countries do not issue shares or share-like instruments. A shareholder owns part of the company; a bondholder does not. She has no voice in management. On the margin, even the smallest shareholder does. A corporate bond, after all, is merely a claim to some predefined part of the corporation's profit. In the case of sovereign bonds, it is a claim on a country's primary surplus. Given these distinctions, sovereign bonds do not share the fate of shares. There is no association with a commercial undertaking.

Sovereign bonds typically serve general budgetary purposes; for lack of association with a commercial undertaking, such bonds will generally fail to qualify as "investments." ICSID could still have jurisdiction over sovereign bonds associated with a transaction that, on its own merits, amounted to an "investment." 111 Bonds tied directly to specific projects, such as railway or power plant construction, come to mind. ${ }^{112}$

${ }^{110}$ So far, no ICSID tribunal has explicitly recognized this feature. I submit that recognition is appropriate. Christoph Schreuer, The Concept of Expropriation Under the ETC and Other Investment Protection Treaties, in INVESTMENT ARBITRATION AND THE ENERGY CHARTER TREATY 108, 139 (Clarisse Ribeiro ed., 2006), mentions a "broad concept of economic rights that are necessary for the investor to pursue its business successfully" (emphasis added); Thomas Waelde \& Abba Kolo, Environmental Regulation, Investment Protection and "Regulatory Taking" in International Law, 50 INT'L \& COMP. L.Q. 811, 835 (2001) (emphasis added), speaks of "a combination of rights in a commercial, corporate setting and under a regulatory regime." In the Fedax Jurisdiction Decision, supra note 63, para. 19, Venezuela's submitted investment meant "the laying out of money or property in business ventures, so that it may produce a revenue or income." See infra notes 113-14 for examples of other BITs.

${ }^{111}$ ICSID has jurisdiction as long as the dispute "arises directly out of an investment." In the Fedax Jurisdiction Decision, supra note 63, para. 24, the tribunal put it thus:

It is apparent that the term "directly" relates in this Article to the "dispute" and not to the "investment." It follows that jurisdiction can exist even in respect of investments that are not direct, so long as the dispute arises directly from such transaction. This interpretation is also consistent with the broad reach that the term "investment" must be given in light of the negotiating history of the Convention.

The CSOB Jurisdiction Decision, supra note 66, para. 32, followed the Fedax Jurisdiction Decision in this respect, noting that

a dispute. . . must be deemed to arise directly out of an investment even when it is based on a transaction which, standing alone, would not qualify as an investment under the Convention, provided that the particular transaction forms an integral part of an overall operation that qualifies as an investment.

${ }^{112}$ In the Compagnie Générale des Eaux case, a mixed commission considered such a bond. Compagnie Générale des Eaux de Caracas [Belgian Waterworks] v. Venezuela (1903), in THE LAW AND PROCEDURE OF INTERNATIONAL TRIBUNALS 78 (Jackson H. Ralston ed., 1926). While the case has no direct bearing on the interpretation of ICSID's Article 25, it might still possess some persuasive force. 
The next section looks at the second leg of the double review. BITs' investment definitions differ: some BITs include sovereign bonds in their definitions, whereas others do not. Even if BITs cover sovereign bonds, a transaction nevertheless needs to fall inside the objective core of Article 25 (see discussion of this objective core above). If unique weight was attached to BIT consent, Article 25's investment requirement would become an empty shell.

\section{BIT' Investment Definitions and Their Relation to Article 25}

BITs use various definitions of investment, which are independent from Article 25. Do BIT definitions cover sovereign bonds (the second step in evaluating ICSID jurisdiction)?

Some BITs cover corporate bonds but explicitly exclude sovereign bonds. ${ }^{113}$ Other BITs include sovereign bonds. ${ }^{114}$ Sacerdoti observed that the "undertaking to respect contractual obligations found in many recent BITs may be relevant also as to equities and debentures issued by a contracting State or by its companies abroad." ${ }^{115}$ Specific sovereign debt restructuring annexes - which limit the host state's treatment obligations (relative to public debt) to national and MFN treatment — are a recent innovation. ${ }^{116}$ They are perhaps the first official recognition that ICSID arbitration could be used by holdout creditors to unravel sovereign debt restructurings approved by a majority of creditors.

It will be useful to take a closer look at the most relevant BITs for bondholders who did not participate in Argentina's exchange. The Argentina-Germany BIT's definition of investment includes "[c]laims to money used to create economic value or claims to performance that have

113 The Bahrain-U.S. BIT limits investments to bonds and debt interests in a company: "Shares, stock, and other forms of equity participation, and bonds, debentures, and other forms of debt interests, in a company." Treaty Between the United States of America and Bahrain Concerning the Encouragement and Reciprocal Protection of Investment, with Annex, Art. 1(d)(2), Sept. 29, 1999, S. TREATY DOC. NO. 106-25 (2000). The North American Free Trade Agreement includes debt securities and loans of enterprises. Public issuers are explicitly excluded. North American Free Trade Agreement, Dec. 17, 1992, Can.-Mex.-U.S., Art. 11.39, 32 ILM 289 \& 605 (1993). The Canadian Model BIT, at < http://ita.law.uvic.ca/documents/Canadian2004-FIPA-model-en.pdf $>$, also excludes debt instruments issued by public entities.

114 The 2004 U.S. Model BIT, at < http://www.ustr.gov/assets/Trade_Sectors/Investment/Model_BIT/ asset_upload_file847_6897.pdf $>$, covers, among others, "bonds, debentures, other debt instruments, and loans." A similar, wide definition is found in the Japan-South Korea BIT: "[E]very kind of asset ... including ... . bonds, debentures, loans, and other forms of debt [as well as] rights under contracts." Agreement Between the Republic of Korea and Japan for the Liberalisation, Promotion and Protection of Investment, Mar. 22, 2002, Art. 1(2), Treaty No. 17, Ministry of Foreign Affairs Notification No. 430 (Japan).

115 Sacerdoti, supra note 76, at 307 (emphasis added).

${ }_{116}$ Annex 10-B of the Chile-U.S. Free Trade Agreement, June 6, 2003, limits obligations relative to public debt to national and MFN treatment: "The rescheduling of the debts of Chile . . owed to the United States and the rescheduling of its debts owed to creditors in general are [subject only to] article 10.2 [MFN treatment] and 10.3 [national treatment]." See U.S.-Australia Free Trade Agreement, May 18, 2004, Art. 11.17(4)(c); U.S.-Morocco Free Trade Agreement, June 14, 2004, Art. 10.27(c); U.S.-Central America-Dominican Republic Free Trade Agreement, Aug. 2, 2005, Art. 10.28(c). Similar policy considerations are apparent in the U.S.-Uruguay BIT, Nov. 4, 2005. Its Annex G qualifies treatment standards with respect to sovereign debt: "No claim that a restructuring of a debt instrument issued by Uruguay breaches an obligation under Articles 5 through 10 [fair and equitable treatment, full protection and security, expropriation] may be submitted to . . . arbitration . . . if the restructuring is a negotiated restructuring . ..." U.S. free trade agreements and bilateral investment treaties are available at the Office of the U.S. Trade Representative Web site, $<$ http://www.ustr.gov $>$. "Negotiated restructuring" is defined as restructuring to which a specified majority (usually two-thirds) of creditors has consented. 
economic value." 117 The Argentina-Italy BIT extends coverage to "debentures, private or public bonds or any other right connected to services or performances having an economic value and capitalized income." 118 The plain text of both BITs thus indicates that the parties consented to the inclusion of sovereign bonds and other debt instruments.

By contrast, the Argentina-U.S. BIT covers "claim[s] to money or a claim to performance having economic value and directly related to an investment." 119 Not all claims to money or performance are included in this particular BIT. They need to be associated with transactions that are investments in their own right. In contrast to the German and Italian BITs with Argentina, the requirement of an association with an investment proper suggests that sovereign bonds used for general budgetary purposes are outside the scope of the Argentina-U.S. BIT. ${ }^{120}$

From BIT coverage it does not follow that sovereign bonds also qualify as investments under Article 25. BITs' separate, bilateral definition of investment does not determine the scope of the multilateral Article 25. Many commentators mistakenly interpret Article 25's definitional silence concerning "investment" as legitimating an elastic notion of investment, but the failure to reach consensus cannot be used to adopt a broad notion by default. ${ }^{121}$ Reading away Article 25 's investment requirement in this manner is at odds with commonly accepted principles of treaty interpretation. Putting exclusive weight on BIT consent deprives Article 25 of its core purpose.

The Joy Mining Tribunal put it thus:

[T] hat the Convention has not defined the term investment does not mean, however, that anything consented to by the parties might qualify as an investment under the Convention. The Convention itself, in resorting to the concept of investment in connection with jurisdiction, establishes a framework to this effect: jurisdiction cannot be based on something different or entirely unrelated. ... [T] here is a limit to the freedom with which the parties may define an investment if they wish to engage the jurisdiction of ICSID tribunals .... Otherwise Article 25 and its reliance on the concept of investment, even if not specifically defined, would be turned into a meaningless provision. ${ }^{122}$

Some BITs require a territorial link over and above Article 25. In such cases, a double review of this typical element is necessary. Sacerdoti questioned whether sovereign bonds would be

${ }^{117}$ Article 1.1(c) of the Argentina-Germany BIT, Apr. 9, 1991, at < http://www.unctad.org/sections/dite/iia/ docs/bits/germany_argentina_sp.pdf $>$, includes "los derechos a fondos empleados para crear un valor económico o a prestaciones que tengan un valor económico."

${ }_{118}$ Article 1(c) of the Argentina-Italy BIT, May 22, 1990, at < http://www.unctad.org/sections/dite/iia/docs/ bits/italy_argentina_it.pdf $>$, includes “obbligazioni, titoli pubblici o privati o qualsiasi altro diritto per prestazioni o servizi che abbiano un valore economico, come altresì redditi capitalizzati."

119 Treaty with Argentina Concerning the Reciprocal Encouragement and Protection of Investment, Nov. 14, 1991, Art. 1(a)(iii), S. TREATY DOC. 103-2 (1993).

${ }^{120}$ See Article I.4 (h) of the Morocco-U.S. BIT, limiting coverage to "a claim to money or a claim to performance having economic value, and associated with an investment." Treaty Between the U.S and Morocco Concerning the Encouragement and Reciprocal Protection of Investments, July 22 ,1985, S. TREATY DOC. 99-18 (1986).

${ }^{121}$ For a spirited defense of this view, see Prosper Weil, dissenting in Tokios Tokelés $v$. Ukraine, who lucidly lays out the philosophical case for separating consent from the requirements of Article 25 (see, in particular, paragraphs 28-30). Tokios Tokelés v. Ukraine, ICSID Case No. ARB/02/18, Jurisdiction (Apr. 29, 2004) ("the silence of the Convention ... does not leave the matter to the discretion of the parties" (para. 19)). In that case, the core question was whether jurisdiction under Article 25 existed for a dispute between the Ukraine and a Ukrainian national. See Markus Burgstaller, Nationality of Corporate Investors and International Claims Against the Investor's Own State, 7 J. WORLD INVESTMENT \& TRADE 857 (2006).

${ }^{122}$ Joy Mining Jurisdiction Award, supra note 50, paras. 49, 50. 
covered investments under the typical BIT. Since issuance of sovereign bonds would not meet the requirement of a territorial link with the host country, protection would not extend to sovereign bonds, ratione loci. ${ }^{123}$ Yet a number of prominent cases interpret the BIT's territorial requirement liberally. In all three cases, the jurisdictional defense that the BIT required an "investment in the territory" was to no avail.

In Fedax, Venezuela duly disputed the tribunal's jurisdiction on the ground that Fedax had not made an investment "in the territory" of the contracting parties as prescribed by the BIT. In dismissing this argument, the tribunal stated that it "is a standard feature of many international financial transactions that the funds involved are not physically transferred to the territory of the beneficiary, but put at its disposal elsewhere." ${ }^{124}$

The tribunal substituted the territorial requirement with a much broader "utilized by the beneficiary of the credit." This reading is at odds with the plain language of the BIT. The tribunal's reasoning is also circular, as it infers the meaning of "investment" from prominent characteristics of international financial transactions. The tribunal mistakenly premised its holding on the postulated assumption that the BIT's contracting parties desired to cover all international financial transactions. Instead, the tribunal should have clarified the meaning of investment under Article 25 and the BIT first-and only then evaluated whether the specific transaction amounted to an investment. ${ }^{125}$

Two other ICSID cases addressed BITs' territorial requirements. SGS v. Philippines held that preshipment inspection services conducted in a port outside the host country did not preclude qualification as an investment, since the contract's main purpose was the delivery of inspection certificates in the Philippines. ${ }^{126}$ Some business activity related to the investment in the host state is necessary; the holding in SGS v. Pakistan was that "certain expenditures in . . Pakistan" and the "injection of funds into the territory" satisfied the BIT's territorial link. ${ }^{127}$

In Fedax, in sharp contrast to the two SGS cases, the holders of promissory notes never expended financial resources in Venezuela for a commercial undertaking, and they provided no service whose point of delivery was in the territory of the other contracting party. If the proceeds of a sovereign bond are deposited or used for transactions outside the issuing country, it is doubtful whether such a bond would meet a territorial BIT condition. ${ }^{128}$ Using funds in the territory of another country is insufficient. Since there is never any commercial activity in the debtor country, sovereign bonds might fail to fulfill the BIT's territorial requirement.

The argument developed in this section may be summarized as follows. Article 25's silence on the definition of investment is content neutral. Typical elements circumscribe the objective

\footnotetext{
${ }^{123}$ Sacerdoti, supra note 76 , at 308. 88.

${ }^{124}$ Fedax Jurisdiction Decision, supra note 63, para. 41; see CSOB Jurisdiction Decision, supra note 66, para.

${ }^{125}$ As I argued above, see supra text accompanying notes 104-09, the notes in the Fedax case would almost certainly fail the territorial link required under Article 25.

${ }^{126}$ SGS-Philippines Jurisdiction Award, supra note 50, paras. 57, 99-112. In an obiter dictum (paragraph 10) the SGS-Philippines tribunal appeared to object to the "very broad definition of territoriality" in the Fedax Jurisdiction Decision, supra note 63.

${ }^{127}$ SGS-Pakistan Jurisdiction Decision, supra note 47, paras. 75-77, 136.

128 The argument that money is fungible and that the proceeds from the sovereign bonds could therefore free financial resources in the host country for other uses is to no avail; such a reading is at odds with the plain meaning of "in the territory."
} 
core meaning of "investment," which is independent of the BIT. This core defines, in effect, the outer perimeter of ICSID jurisdiction. Article 25's objective core is to be evaluated primarily against the nature of the transaction. If, instead, the term "investment" were limitless, then ICSID arbitration could be deployed to the detriment of bondholders of third countries. ${ }^{129} \mathrm{~A}$ purely bilateral exercise of jurisdiction could also have substantial extraterritorial reach.

The basis for ICSID jurisdiction over debt instruments is weak. In many cases, sovereign bonds will fail to display typical features of an investment. Careful inspection of existing case law does not support ICSID jurisdiction over debt instruments, in general, and sovereign bonds, in particular.

The following section looks at how domestic jurisdiction clauses and collective action clauses interact with ICSID jurisdiction. The incomplete separation of contractual and treaty claims implies that ICSID tribunals owe deference to national courts in the presence of exclusive domestic jurisdiction or CACs.

\section{RESOLVING OVERLAPPING JURISDICTION OVER SOVEREIGN BONDS}

Sovereign bonds are typically governed by the municipal law of an important financial center and subject to their jurisdiction. ICSID could enjoy concurrent jurisdiction to the forum chosen by the bond. While international law currently has few rules to resolve such conflicts, overlapping jurisdiction is not unusual in international investment law. ${ }^{130}$ Yet because sovereign bonds lack a specific connection to ICSID, arbitration under its auspices threatens to upset the sovereign debt market and dispute resolution in national courts.

Unlike old concession contracts or commercial contracts with governments, sovereign bonds do not contain arbitration clauses. ${ }^{131}$ Sovereign bonds contracts are concluded as a whole, and ICSID arbitration — not contemplated when the contract was concluded - threatens to unravel the unity of the bond's contractual bargain. I conclude that exclusive domestic jurisdiction and CACs in sovereign bonds bar recourse to ICSID arbitration in most circumstances.

\section{The Slippery Slope from Contractual to Treaty Causes of Action}

How do sovereign bonds come under the ambit of international law? International law appears on the scene when a bondholder requests ICSID arbitration and alleges violations of the BIT's treatment standards. In principle, there are two nonexclusive routes of relief: contract and treaty. The bondholder could pursue contractual claims under the bond concurrently with

${ }^{129}$ ICSID awards are equivalent to final judgment in ICSID member countries. See ICSID Convention, supra note 28, Arts. 53-55.

${ }^{130}$ For a general discussion of such conflicts, see Vaughan Lowe, Overlapping Jurisdiction in International Tribunals, 1999 AUSTRALIAN Y.B. INT'L L. 191.

${ }^{131}$ The exception to this general rule is Brazilian bonds, some of which incorporate UNCITRAL arbitration clauses. So far, holdout litigation has almost invariably been undertaken in domestic courts. The reasons are manifold. For one, sovereign bonds are complex financial transactions governed by municipal law. Moreover, sovereign bonds with arbitration clauses (ICSID or otherwise) could implicitly recognize the possibility of eventual default and thereby negatively affect their marketability; the inclusion of arbitration clauses is therefore generally avoided, leaving domestic courts the forum of choice. Finally, sovereign bonds are "conservative" financial instruments whose contractual terms display tremendous inertia against change (for example, to include arbitration clauses). 
treaty claims. Alternatively, she could eschew her contractual claim for repayment and allege expropriation under international law.

Article 25 of the ICSID Convention draws no distinction between treaty and contractual claims. ICSID jurisdiction may well extend to purely contractual disputes, as long as the dispute arises directly out of an investment. ${ }^{132}$ That said, contractual and treaty claims operate on separate planes. A country's default on a sovereign bond does not, in itself, imply a breach of BIT treatment obligations. ${ }^{133}$ As an exception to this general rule, umbrella clauses are said to elevate all contractual to treaty claims; ${ }^{134}$ in the presence of an umbrella clause, a sovereign bond default could ipso facto constitute an internationally wrongful act.

ICSID tribunals have struggled to delimit contractual from treaty causes of action. ${ }^{135}$ Some awards strictly distinguish the "contractual" and "treaty" spheres. At times the two cannot be disentangled since the unity of the transaction mandates joint deliberation. The 1903 Woodruffcase called for an analysis of the "fundamental basis of the claim" whenever treaty and contractual elements are intertwined. ${ }^{136}$ The test to determine that basis is objective. Even if a bondholder characterizes her claim as BIT based, the tribunal could conclude otherwise - that the claim is essentially contractual.

Municipal law governs sovereign bonds. National courts almost invariably enjoy jurisdiction. Of outstanding sovereign bonds, only a small fraction provide for dispute settlement under UNCITRAL. No sovereign bond contains references to arbitration under ICSID. Sovereign bonds governed by municipal law lack a "specific connection" to ICSID. ${ }^{137}$ Their configuration departs from the prototypical ICSID foreign investment dispute: the host country's law does not govern the bond; its courts do not enjoy jurisdiction; and bondholders are guaranteed access to an impartial forum, the municipal courts of a financial center.

On the requirement of a specific connection to ICSID, Joy Mining explained:

$[\mathrm{M}]$ any ICSID and other arbitral decisions . . . have progressively given a broader meaning to the concept of investment. But in all those cases there was a specific connection to ICSID, either because the activity in question was beyond doubt an investment or because there

132 SCHREUER, supra note 50, at 127-34.

${ }^{133}$ BORCHARD \& WYNNE, supra note 55, at 115; F. V. García-Amador, Second Report on State Responsibility, [1957] 2 Y.B. INT'L L. COMM'N 104, 117, UN Doc. A/CN.4/106. In negotiations for the multilateral agreement on investment, there was also strong support for this proposition. Organisation for Economic Co-operation and Development, Multilateral Agreement on Investment: Commentary to the Consolidated Text, at 23-24 (1998). The draft agreement, along with the commentary, is available on the OECD Web site, <http://www.oecd.org >.

${ }^{134}$ Umbrella clauses contain the host state's general commitment to honor all contractual undertakings. A treaty violation goes hand-in-hand with the contractual breach. Christoph Schreuer, Travelling the BIT Route: Of Waiting Periods, Umbrella Clauses and Forks in the Road, 5 J. WORLD INVESTMENT \& TRADE 231 (2004), treats umbrella clauses in detail.

135 This question attracted much attention recently. See Emmanuel Gaillard, Investment Treaty Arbitration and Jurisdiction over Contract Claims-the SGS Cases Considered, in LEADING CASES, supra note 2, at 325; Christoph Schreuer, Investment Treaty Arbitration and Jurisdiction over Contract Claims - the Vivendi I Case Considered, in LEADING CASES, supra note 2, at 281; Yuval Shany, Contract Claims vs. Treaty Claims: Mapping Conflicts Between ICSID Decisions on Multisourced Investment Claims, 99 AJIL 835 (2005).

136 (U.S. v. Venez.), 9 R.I.A.A. 213 (1903). The ad hoc committee in the Vivendi Annulment Decision, for example, relied on this finding. Compañia de Aquas del Aconquija, S.A. v. Argentine Republic, ICSID Case No. ARB/97/3, Annulment (July 3, 2002) [hereinafter Vivendi Annulment Decision].

137 Joy Mining Jurisdiction Award, supra note 50, para. 59. The Historical Salvors Jurisdiction Award, supra note 50 , paras. 119-29, introduced the related concept of "readily recognizable" investment into ICSID case law. 
was an arbitration clause involved. The same holds true of concession contracts in which the investor is called to perform a public service on behalf of the State. ${ }^{138}$

The tribunal's restraint in exercising jurisdiction over contracts entirely outside ICSID's sphere lends further support to the conclusion that ICSID lacks jurisdiction over sovereign bonds.

When sovereign bonds are issued, the only remedies contemplated are contractual ones in national courts; ICSID arbitration is not. Since litigation of these complex technical contracts occurs invariably in national courts, the sudden invocation of ICSID arbitration would undermine legal certainty in the sovereign debt market and, more generally, for all international financial transactions. Successful bondholder arbitration before ICSID would upset long-standing expectations. If future ICSID tribunals follow Fedax, the implications for international financial transactions are enormous. The unity of the contractual bargain negotiated between bondholders and the country could also dissolve.

I now turn to whether domestic-jurisdiction clauses constitute a bar to ICSID arbitration. Exclusive-jurisdiction clauses in the bond could prevent ICSID from hearing bondholder claims.

\section{Choice of Forum in Sovereign Bonds}

The following is a typical formulation of a nonexclusive domestic-jurisdiction clause in a sovereign bond governed by New York law:

Country X will irrevocably submit to the non-exclusive jurisdiction of any New York State or Federal court in New York City in any related proceeding i.e., any suit, action or proceeding arising out of or relating to the debt securities and Country $\mathrm{X}$ will irrevocably agree that all claims in respect of any related proceeding may be heard and determined in such New York State or Federal court.

This wording (with emphasis added) confers nonexclusive jurisdiction on New York State or federal courts. The clause places this sovereign bond firmly in the ambit of New York law but does not as such bar ICSID arbitration. Since arbitration of sovereign bonds is a novel (and recent) idea, it is not surprising that the clause is silent on ICSID or UNCITRAL arbitration. Moreover, consent to ICSID jurisdiction is typically given in a BIT, with no need for a jurisdictional clause in the bond itself.

The following is a clause, occasionally found in sovereign bonds, that establishes exclusive domestic jurisdiction: "The parties agree that any claim or suit which may arise in relation hereto or to the Bonds issued shall be subject to the exclusive jurisdiction of the Courts and Tribunals of Madrid, and expressly waive any other venue to which they may be entitled." This derogation clause (emphasis added) excludes jurisdiction by "any other venue." Would this clause bar an ICSID tribunal from hearing treaty and contractual claims? ${ }^{\text {139 }}$

${ }^{138}$ Joy Mining Jurisdiction Award, supra note 50, para. 59.

${ }^{139}$ An unexplored question is the possibility of investors forbearing (waiving) ICSID arbitration by agreeing to the exclusive jurisdiction of national courts. Space constraints do not allow further exploration here. In Aguas del Tunari v. Bolivia S.A., ICSID Case No. ARB/02/3, Respondent's Objections to Jurisdiction (Oct. 21, 2005), the tribunal recognized the possibility of waiving ICSID arbitration for the first time. The mixed commission in Woodruff presented an interesting analysis specifically concerning sovereign bonds. 
Absence of the term "exclusive" is an insufficient basis for concluding that ICSID arbitration is available. ${ }^{140}$ In particular, where several modes of adjudication are listed in the bond, a careful interpretation might reveal that such jurisdiction was intended to be exclusive. A good example is a sovereign bond that foresees jurisdiction in two or more municipal jurisdictions or in one municipal jurisdiction along with concurrent UNCITRAL arbitration. Sovereign bonds often provide for the jurisdiction of the issuing country and an important financial center.

The provisions for arbitration included in BITs and the jurisdictional clauses of sovereign bonds are on a par, with neither subordinate to the other. The two modes of host state consent to dispute settlement differ in one respect only: one is given in a BIT, the other in a contract governed by municipal law. ${ }^{141}$ In both cases, the parties to the agreement are the host state and the foreign investor. No hierarchy exists between them. The agreement to submit to ICSID arbitration is on par with the contractual agreement to submit to the jurisdiction of municipal courts.

Which principles guide resolution in ICSID awards when the two modes of consent conflict? In SPP v. Egypt, the tribunal held that an exclusive specific-arbitration agreement would take precedence over the BIT concluded between the investor's state of nationality and Egypt; the basis of this decision was the principle generalia specialibus non derogant and posterior tempore, potior iure. ${ }^{142}$ The BIT hence does not affect a preexisting dispute resolution clause. Thus, applying the principle of lex specialis, the tribunal in SGS v. Philippines considered the exclusive domestic-jurisdiction clause to be controlling; ${ }^{143}$ a specific contractual dispute resolution clause took priority over the BIT.

What are the implications for sovereign bonds? As we saw, municipal law governs these debt instruments. They have no specific connection to ICSID. Application of the lex specialis and generalia specialibus non derogant principles to sovereign bonds that provide for exclusive domestic jurisdiction prevents ICSID from hearing such claims. This outcome preserves the unity of the bond's bargain. The bondholder cannot request ICSID arbitration on the bond while simultaneously disregarding a valid jurisdictional clause in the very same contract. Conversely, nonexclusive jurisdiction of national courts might leave ICSID jurisdiction untouched.

The next section demonstrates how recourse to ICSID arbitration could seriously undermine the international community's collective action policy adopted following the wave of financial crises at the end of the last century. While there are no CACs in the bonds held by creditors who did not participate in Argentina's exchange, the interaction of ICSID arbitration and CACs is a major, future concern of international public policy. I explain how holdout creditors could tice).

${ }^{140}$ SGS-Philippines Jurisdiction Award, supra note 50, para. 134; see id., paras. 149-53 (surveying arbitral prac-

${ }^{141}$ For insightful analysis of the hierarchy between the two modes of consent, see, in particular, Zachary Douglas, The Hybrid Foundations of Investment Treaty Arbitration, 2003 BRIT. Y.B. INT'L L. 151, 248. His view is controversial. For example, the SGS-Philippines tribunal suggested that a BIT and a contract governed by national law are on a different footing. SGS-Philippines Jurisdiction Award, supra note 50, para. 142.

${ }^{142}$ Southern Pacific Properties Ltd. v. Egypt, Jurisdiction, ICSID Case No. ARB/84/3, para. 83 (Apr. 14, 1988), 3 ICSID REP. 131 (1995). Similarly, in the SGS-Philippines Jurisdiction Award, supra note 50, para. 141, the tribunal relied on generalia specialibus non derogant to give precedence to the parties' contractual choice of forum for contractual causes of action.

143 SGS-Philippines Jurisdiction Award, supra note 50, para. 141. Antonio Crivellaro stressed in his dissent (paragraphs 9-10) that since the BIT only offers arbitration, there is no arbitration agreement until the investor initiates arbitration. 
claim that the use of CACs approved by the requisite majority of bondholders violated BIT treatment standards.

\section{Preclusion of ICISD Arbitration by Collective Action Clauses}

This section explores whether CACs change the substance of bondholders' potential treaty claims. Could nonparticipating bondholders bring a treaty cause of action based on bonds not tendered in the debt restructuring? With regard to contractual obligations, the situation is clear-cut. As a contractual mechanism for collective action, it is beyond doubt that the valid exercise of CACs alters the contractual obligations under the bond. It is submitted that CACs have similar effects for treaty causes of action.

CACs are standard clauses in sovereign bonds governed by English or Japanese law and have recently become the market standard in sovereign bonds governed by New York law. The increased prominence of CACs in New York law, which is the choice of law for many sovereign bonds, is due to a concerted effort by the international community-and by the Group of Ten, in particular - to secure the general use of CACs in order to facilitate the orderly resolution of sovereign debt crises. ${ }^{144}$ While CACs have yet to be tested in actual crises, the view is widespread that these clauses will diminish the holdout problem in future sovereign debt restructurings.

CACs come in two forms: majority amendment and majority enforcement clauses. Majority amendment clauses allow a qualified majority of bondholders, typically 75 percent, to bind all creditors to the terms of a sovereign debt restructuring. Majority enforcement provisions limit the ability of individual creditors to enforce: they require an affirmative vote of 25 percent to accelerate and enforce a bond after a default.

CACs have no equivalent in BITs. In 2002, when the international community started to advocate use of CACs to facilitate sovereign debt restructurings, municipal courts were the sole venue for sovereign debt litigation. At the time, ICSID arbitration on sovereign bonds, or arbitration under any other set of arbitral rules for that matter, was not contemplated. The prima facie limited coverage of CACs - their failure to include arbitration-opens up a new window of opportunity for holdout litigation. The importance of this potential loophole for sovereign debt markets cannot be overemphasized. Consider the following scenario.

ICSID tribunals could conceivably hear treaty claims concerning sovereign bonds despite the legitimate exercise of CACs, which would become ineffective in binding nonparticipating creditors. If CACs were to leave treaty claims untouched, then they would bar only contractual causes of action originating in the bond contract. Bondholders might be able to obtain compensation even though the contractually prescribed majority of bondholders accepted the sovereign debt restructuring. Recourse to ICSID arbitration could thus create a legal gap in the international community's collective action policy.

Sovereign debt restructurings via CACs do not breach the terms of sovereign bonds. ICSID tribunals ought to pay deference to the exercise of such contractually agreed clauses. Whenever nonparticipating bondholders seek to obtain more favorable recovery through ICSID arbitration than they would have had under the contractual terms of the restructured bond, the valid

${ }^{144}$ See supra note 14. 
exercise of CACs generally bars ICSID tribunals from hearing treaty causes of action; nonparticipating creditors may rely on treaty claims only if the country implemented a coercive bond exchange.

Breach and coercion need to be assessed primarily on the basis of the bond's governing law. Scenarios might exist where the BIT claim is entirely separable from any contractual breach. Manifest discrimination against nonparticipating creditors compared to those creditors who chose to go along with the restructuring could lead to such severability. In particular, manifest discrimination could violate the fair and equitable standard. ${ }^{145}$ Tribunals would then not be bound by CACs and could exercise jurisdiction even in the absence of a contractual breach. This question deserves closer scrutiny.

Moreover, the government's proposed restructuring is only the proximate cause of any loss to bondholders. Typically, in such an exchange a country proposes new financial terms on its outstanding indebtedness on a take-it-or-leave-it basis. With the help of CACs, certain key terms of the bonds are modified. This modification comes into effect, however, only with the affirmative vote of a qualified majority of bondholders, typically 75 percent. The direct cause of any loss, however, is the acceptance of exchange by the contractually required majority. Characterizing such a restructuring agreement as sovereign action is difficult. If it is only an agreement, not a governmental measure, then it cannot violate the BIT's treatment standards.

The next section explains why ICSID tribunals owe deference to clauses for exclusive domestic jurisdiction and collective action.

\section{Preserving the Unity of the Contractual Bargain}

Extending CACs' preclusive effect to treaty causes of action preserves the unity of the contractual bargain. ${ }^{146}$ If, despite an exclusive domestic jurisdiction clause in the bond or a valid exercise of CACs under the terms of the bond, the bondholder requests arbitration, then she pleads the breach of one term, while not observing another of the very same contract. ICSID jurisdiction in such circumstances could effectively allow one party to change the contractual bargain at its discretion and to override the CACs. Such an outcome is inconsistent with ICSID's aim of contributing to a stable and positive investment climate. ${ }^{147}$ It would also run deeply contrary to expectations in the sovereign debt market - and in international financial transactions, more generally — thereby undermining legal certainty.

ICSID case law often safeguards the contractual bargain. SGS v. Philippines, for example, held:

It is not to be presumed that such a general provision [the BIT] has the effect of overriding specific provisions of particular contracts, freely negotiated between the parties. . . [A BIT is] a framework treaty, intended by the State Parties to support and supplement, not to override or replace, the actually negotiated investment arrangements made between the investor and the host State." 148

\footnotetext{
145 The fair and equitable treatment standard is examined in greater detail infra text accompanying notes 212-

${ }^{146}$ Douglas, supra note 141 , at 243.

${ }^{147} \mathrm{Id}$. at 248 (emphasizing the importance of upholding the collective will of both parties, in view of ensuring continued broad support for investment treaty arbitration).

${ }^{148}$ SGS-Philippines Jurisdiction Award, supra note 50, para. 141.
} 42. 
Telenor $v$. Hungary found that "to invoke the MFN clause to embrace the method of dispute resolution is to subvert the intention of the parties to the basic treaty, who have made it clear that this is not what they wish." 149 If ICSID had jurisdiction, and if arbitration is not barred by exclusive domestic jurisdiction clauses or CACs, the next step in successful ICSID arbitration is proving a violation of BIT treatment standards.

\section{SOVEREIGN DEFAULT AS TRIGGER FOR STATE RESPONSIBILITY}

The central question in the following section is whether sovereign debt restructurings or defaults on sovereign bonds trigger international liability. ${ }^{150}$ Only if the bondholder was to demonstrate violation of a BIT treatment standard would she be entitled to compensation under international law. From the perspective of participating bondholders, any compensation paid to nonparticipating creditors for violation of BIT obligations could amount to preferential payment-in which case the strategy of holding out for full repayment on the bonds could potentially succeed.

This section first takes one step back to examine the nature of breach for sovereign default, along with the applicable law. Subsequently, four specific treatment standards will be examined: MFN treatment, national treatment, expropriation, and fair and equitable treatment. ${ }^{151}$

\section{The Nature of Breach for Sovereign Default}

Modern sovereign bonds are governed by the municipal law of a foreign financial center, not by international law. Accordingly, the sovereign bond repayment claim is grounded in some municipal law. This law shapes the claim's content: its existence, ownership, and scope. BITs, by contrast, prescribe whether a contractual right is afforded certain treaty protections. The applicable law has no bearing on jurisdiction. Whether an ICSID tribunal enjoys jurisdiction over contractual claims in addition to treaty claims is a function only of the interaction between the ICSID Convention and the applicable BIT.

The separation of treaty and contractual claims is incomplete. Limited recourse to municipal law to determine a treaty breach is necessary. It is commonly asserted that once municipal law has recognized a property or contractual right, the treaty regime controls. Nevertheless, although international law does assume primacy over municipal law, the takeover is incomplete. Postulating a complete divorce of international from municipal law on the basis of this time-honored tenet is mistaken-for two reasons.

First, BITs lay down standards of treatment. By definition, these standards are the ground rules for the host state's behavior. Investment treaties do not purport to specify the contours of the claim in question - only the yardsticks against which the host state's conduct is to be judged. Since the underlying right of repayment will be one created by the municipal law governing the sovereign bond, an international tribunal would typically not be able to consider the related treaty claim in isolation from the underlying right itself. More generally, abstracting

\footnotetext{
149 Telenor Mobile Communications A.S. v. Hungary, ICSID Case No. ARB/04/15, Award, para. 95 (Sept. 13, 2006).

${ }^{150}$ On responsibility for debt generally, see AUGUST REINISCH, STATE RESPONSIBILITY FOR DEBTS: INTERNATIONAL LAW ASPECTS OF EXTERNAL DEBT AND DEBT RESTRUCTURING (1995).

${ }^{151}$ It is important to keep in mind that these treatment standards differ across BITs.
} 
entirely from applicable municipal law is impossible. General principles of municipal law are important sources of international law. ${ }^{152}$ Borrowing from Hersch Lauterpacht, the notion that if a transaction is protected by international law, it is for that reason at the same time outside the sphere of municipal law is impossible and, if accepted, is potentially subversive of the international investment regime. ${ }^{153}$ Proper consideration of treaty claims requires a thorough examination of the contractual claim. In this limited respect, recourse to municipal law is necessary.

Second, investment law and, more generally, international law are underdeveloped in a central respect. Under the general principles of law found in many municipal systems, extraordinary circumstances may occasionally warrant a modification of contractual claims. The lack of payment capacity and the use of general regulatory powers in national economic emergencies are pertinent examples. ${ }^{154}$ Current international law provides only broad guidance as to which circumstances justify noncompliance with international obligations. ${ }^{155}$ The lex contractus and general principles of law contain more nuanced answers. ${ }^{156}$ Recourse to municipal law is also relevant for abstract terms such as fair and equitable treatment.

Against this background-which concerns, in this context, the basis for determining breach of treatment standards-I turn to four potential bases of international liability on sovereign bonds. MFN and national treatment are discussed together due to their structural similarities. Cases have been selected to illustrate the main implications of these four treatment standards for sovereign bonds. ${ }^{157}$

\section{Most-Favored-Nation and National Treatment}

The national treatment and MFN clauses in BITs allow bondholders to assert discrimination based on nationality. National treatment clauses could obligate the issuing country to grant the same treatment to covered foreign bondholders as to its domestic bondholders, or to all creditors more generally. MFN clauses could allow foreign bondholders to benefit from more-favorable privileges granted to third-country bondholders. ${ }^{158}$

${ }^{152}$ International law is part of the general system of law. See Statute of the International Court of Justice, Art. 38(1), at < http://www.icj-cij.org > . The most important doctrinal contribution is by HERSCH LAUTERPACHT, PRIVATE LAW SOURCES AND ANALOGIES OF INTERNATIONAL LAW: WITH SPECIAL REFERENCE TO INTERNATIONAL ARBITRATION (1927).

${ }^{153}$ Certain Norwegian Loans (Fr. v. Nor.), 1957 ICJ REP. 9, 37 (July 6) (Lauterpacht, J., sep. op.).

${ }^{154}$ For general international law, see Article 25 (state of necessity) of the International Law Commission's Articles on Responsibility of States for Internationally Wrongful Acts, in Report of the International Law Commission on the Work of Its Fifty-third Session, UN GAOR, 56th Sess., Supp. No. 10, at 43, UN Doc. A/56/10 (2001), reprinted in JAMES CRAWFORD, THE INTERNATIONAL LAW COMMISSION'S ARTICLES ON STATE RESPONSIBILITY: INTRODUCTION, TEXT AND COMMENTARIES (2002). The tribunal in the CMS Award, supra note 38, paras. 214-27, 304-89, dismissed Argentina's state of necessity defense despite a serious financial crisis. The tribunal in $L G \& E$ Energy Corp. reached the opposite conclusion on identical facts; for a critique of this divergence, see Schill and Waibel, supra note 38.

${ }^{155}$ In truth, the existing universe of BITs displays many different shades of treatment standards.

${ }^{156}$ A good example of this approach is Noble Ventures Inc. v. Romania, ICSID Case No. ARB/01/11, Award (Oct. 12, 2005), at < http://ita.law.uvic.ca/documents/Noble.pdf $>$, in which the tribunal's definition of the arbitrary treatment standard is guided by a commonality of municipal law. For further discussion see infra text accompanying notes $227-29$.

${ }^{157}$ It is not my aim here to present a comprehensive treatment of the case law relating to these standards.

${ }^{158}$ Some BITs include specific debt-restructuring annexes that limit treatment obligations on public debt to MFN and national treatment. See supra note 116. 
Modern sovereign bonds are atomized debt instruments: countries will often know neither the identities nor the nationalities of their bondholders. When a sovereign debt restructuring becomes necessary, this informational constraint may be severe. Discriminating between domestic and foreign bondholders was easier when nationals of the issuing country bought mainly domestic bonds and foreign citizens bought mainly external bonds. But now, even if a country desired to treat bondholders unequally, purposeful discrimination against foreign bondholders within a single bond issue, while theoretically possible, is exceedingly difficult as a practical matter.

Today, the primary fault line of discrimination is between bondholders who participate in a restructuring and those who choose to retain their old bonds. ${ }^{159}$ The first type of discrimination is unlikely to give rise to an MFN claim, as nationality is not the discriminating factor. There might be scenarios in which bondholders of one nationality receive slightly less than bondholders of another (a "larger haircut"), ${ }^{160}$ in apparent violation of the BIT's MFN clause. Nevertheless, while such discrepancies in treatment among external bondholders could arise in principle due to application of different terms in the original bonds, discrimination among foreign bondholders is unlikely to be substantial.

Asserting national treatment claims might be more promising. Domestic debt is often restructured under different terms than external debt. A national treatment claim could arise if a foreign bondholder suffered a deeper haircut in the external debt restructuring than a national bondholder affected by the domestic debt restructuring. Since the original debt instruments will often differ substantially in their legal and financial terms, however, proof of discrimination might be difficult in practice.

The policy implications of MFN and national treatment obligations on sovereign debt remain unexplored. These two treatment obligations could curtail a country's room for maneuver in sovereign debt restructurings. Application of the two clauses raises delicate normative judgments on the unity of the BIT's treaty bargain. ${ }^{161}$ Three main questions come to mind: Could a bondholder who is a national of country $X$ claim the same treatment as bondholder of nationality $Y$ ? Could jurisdiction be extended to cover sovereign bonds? Would the clause allow access to a more favorable dispute settlement mechanism?

The following three examples illustrate these tensions. First, suppose the BIT between countries $X$ and $Y$ restricted treatment obligations with respect to sovereign debt to MFN and national treatment. ${ }^{162}$ Second, assume the BIT between $X$ and $Z$ covered sovereign bonds, but that the BIT between $X$ and $Y$ did not. Finally, imagine the $X-Y$ BIT provided for dispute

\footnotetext{
159 To assure participating bondholders that nonparticipating creditors would not receive more favorable treatment, the Argentine bond exchange included a most-favored-creditor clause. This clause grants participating bondholders the right to compensation, either in cash or kind, that is substantially similar to that received by nonparticipating creditors in any future exchange offer.

160 "Haircut" is the technical term for the write-off from net present value in a debt restructuring.

161 The potential unraveling of the BIT's treaty bargain echoes the argument developed in the earlier section on preserving the unity of the contractual bargain. See supra notes 146-49 and accompanying text. Analysis of this issue is in its infancy. Likewise, if one construes MFN clauses in complex BITs (or free trade agreements) as absolute prohibitions of differentiated treatment according to nationality, the door is open for choosing specific substantive rights and obligations created by those BITS, thereby undermining the contractual bargain. A detailed discussion is beyond the scope of this article.

${ }^{162}$ See U.S.-Uruguay BIT, supra note 116, Annex G (concerning sovereign debt restructuring).
} 
settlement solely in domestic courts. ${ }^{163}$ The first example concerns the BIT's substantive protections, whereas the second and third are procedural. An MFN clause in the $X-Y$ BIT could, based on the more favorable $X-Z$ BIT, enable a $Y$ bondholder to benefit from more expansive jurisdiction, greater scope of protection, or international arbitration.

ICSID case law on propagation of substantive and procedural third-party benefits via the MFN clause is in flux. ${ }^{164}$ Whether MFN clauses cover only substantive or also procedural benefits, including jurisdiction, remains controversial; the more limited goal of this article is to identify some implications of the MFN treatment obligation for sovereign debt restructurings and the procedural bundling of sovereign bond claims.

In Maffezini, the tribunal held that the MFN clause applies to dispute resolution and not solely to BITs' substantive protections. ${ }^{165}$ As a counterbalance, the tribunal also developed a list of judge-made public policy exceptions to MFN clauses (exhaustion of local remedies, ${ }^{166}$ fork-in-the-road provisions, ${ }^{167}$ and submission to a particular arbitral forum). In the tribunal's view these public policy exceptions are implicit in BITs, with the consequence that the central public policy considerations were outside the scope of the MFN clause despite the BIT's failure to mention them explicitly. ${ }^{168}$

\section{Bundling Bondholder Claims}

The progressively more expansive interpretation of MFN clauses à la Maffezini raises the specter of procedural bundling of numerous bondholder claims. ${ }^{169}$ Such bundling would likely require that bondholders with different nationalities be considered to have identical claims. ${ }^{170}$ Invocation of substantial and procedural benefits in third-party BITs via MFN clauses could be the critical ingredient for achieving this goal. As a result, MFN clauses could

\footnotetext{
${ }^{163}$ See the U.S.-Australia Free Trade Agreement, supra note 116, which provides solely for domestic dispute settlement.

164 See Rudolf Dolzer \& Terry Myers, After Tecmed: Most-Favored Nation Clauses in Investment Protection Agreements, 19 ICSID REV. 49 (2005); Dana H. Freyer \& David Herlihy, Most-Favored-Nation Treatment and Dispute Settlement in Investment Arbitration: Just How "Favored" Is "Most-Favored"? 20 ICSID REV. 58 (2005); Ruth Teitelbaum, Who's Afraid of Maffezini? Recent Developments in the Interpretation of Most Favored Nation Clauses, 22 J. INT'L ARBITRATION 225 (2005). The case law is discussed in Emmanuel Gaillard, Establishing Jurisdiction Through a Most-Favored-Nation Clause, N.Y. L.J., June 2, 2005, at 3.

${ }^{165}$ Maffezini v. Kingdom of Spain, ICSID Case No. ARB/97/7, Award (Nov. 13, 2000) [hereinafter Maffezini Award].

166 That is, recourse to arbitration only once domestic remedies prove unsuccessful. See Christoph Schreuer, Calvo's Grandchildren: The Return of Local Remedies in Investment Arbitration, 4 L. \& PRAC. INT'L CTS. \& TRIBUNALS 1 (2005).

167 Once a particular mode of adjudication is chosen, the other is no longer available.

168 See Técnicas Medioambientales Tecmed, S.A. v. Mexico, ICSID Case No. ARB (AF)/00/2, Award, para. 69 (May 29, 2003) [hereinafter Tecmed Award], which applied Maffezini's framework of public policy exceptions and held that the "core matters" of BITs are exempt from the application of the MFN clause. Similarly, in National Grid PLCv. Argentine Republic, Jurisdiction, paras. 86-93 (June 20, 2006), an UNCITRAL tribunal endorsed Maffezini, pointed out that the MFN clause applied to dispute settlement, but could not grant access to a different type of arbitration. By contrast, Plama Consortium Ltd. v. Bulgaria, Jurisdiction, ICSID Case No. ARB/03/24, Jurisdiction, para. 209 (Feb. 8, 2005), considerably restricted the scope of the MFN clause in procedural matters.

169 There are precedents for multiple claimants in ICSID case law.

170 There is no precedent for such procedural bundling under ICSID. It is unclear how ICSID would deal with a large number of parallel bondholder claims. If each bondholder had to pay the registration fee for ICSID arbitration, the costs of arbitration could be prohibitive for all but large bondholders.
} 
be used to replicate some features of "class actions." ${ }^{171}$ Potentially, thousands of bondholders spread across various jurisdictions and subject to different BITs could then pursue their claims in a single ICSID arbitration.

Broches outlined an interesting alternative for pooling sovereign debt claims:

If ... the transaction takes the form of a public bond issue, implying wide distribution, a different treatment is called for. . . . The arbitration agreement could then be concluded between the borrower and the trustee ... and the parties could provide that the latter's nationality shall be exclusively relevant for the determination of the jurisdiction of the Centre ... . Such provisions would seem permitted both by the letter and the spirit of the Convention. ${ }^{172}$

To date, no sovereign bond includes such an arbitration agreement. However, Broches's suggestion begs the question whether an individual bondholder might lack standing to initiate ICSID arbitration. It is conceivable that only the holders of global bonds under the trust indenture or the agency agreement would be deemed to have standing to initiate ICSID arbitration. ${ }^{173}$

A special-purpose vehicle collecting bondholder claims is a related option. Bondholders could transfer legal title to such an entity for the purpose of negotiation and possible litigation. ${ }^{174}$ As long as that vehicle did not lead to an effective change in nationality, it could serve as a possible avenue for collectively enforcing sovereign bonds. Provided that the vehicle has legal personality, it is likely to enjoy standing before ICSID.

Finally, bondholder organizations could collect powers of attorney from thousands of bondholders with the same nationality. Arbitration would then be initiated in the bondholders' own names. On this approach it is immaterial whether there is one or a thousand claimants. Restricting claimants to a single nationality offers the advantage that the BIT obligations with respect to the bondholders would be identical. It remains to be seen how ICSID will cope with such a multitude of claimants. ${ }^{175}$

The next section examines expropriation-another treatment obligation that is commonly found in BITs and that holds promise for sovereign bondholders.

\section{Expropriation}

Defaults on sovereign bonds, as well as a chain of sovereign actions in the lead up to, or during, debt restructurings, could potentially be considered direct or indirect expropriation, with the consequence that the state is bound to pay compensation. A threshold question is the scope

\footnotetext{
${ }^{171}$ It would only be a class in the sense that a large number of bondholders would act together, with their claims being arbitrated as a group. Technically speaking, ICSID has no procedure for U.S.-style class actions. It is also worth noting that, in contrast to the claimants in such actions, a small group of bondholders would not represent the interests of all Argentine bondholders.

172 ARON BROCHES, SELECTED ESSAYS: WORLD BANK, ICSID, AND OTHER SUBJECTS OF PUBLIC AND PRIVATE INTERNATIONAL LAW 248 (1995).

173 The question of standing on global bonds (for definition, see supra note 93) surfaced in U.S. sovereign debt litigation but was not resolved on the merits. See Fontana v. Republic of Argentina, 415 F.3d 238 (2d Cir. 2005).

${ }^{174}$ For example, the Argentine Bond Restructuring Agency Plc (ABRA) incorporated in Ireland after the Argentinean default.

175 If each bondholder had to pay the fees for lodging arbitration under ICSID's Rule 16 individually, this route would become prohibitively expensive. According to ICSID's schedule of fees of July 6, 2005, at <http://www. worldbank.org/icsid/schedule/schedule.htm $>$, a fee of U.S.\$25,000 is "payable to the Center by the party requesting the institution of conciliation or arbitration proceedings under the Convention."
} 
of protected property under the ICSID Convention and a BIT. Are contractual rights subject to expropriation? The extent of coverage is a jurisdictional matter but is discussed here due to the close link with this particular treatment standard.

Because they typically define investments to include contractual rights, BITs lend considerable support to the view that rights arising from a contract are potentially susceptible to expropriation, and in much the same way as tangible property. ${ }^{176}$ BITs do not explicitly address, however, whether default equals expropriation. Scholars similarly maintain that expropriation covers tangible and intangible rights. ${ }^{177}$ Specifically with regard to debt, Feilchenfeld argues that "[d]ebts are property rights; as property rights they are protected by the general rule of maintenance recognized in international law; . . this rule is not restricted to tangible property." ${ }^{178}$ Yet two caveats apply before jumping to the conclusion that sovereign bonds are subject to expropriation.

Some non-ICSID arbitral tribunals treat contractual rights as subject to expropriation only if they are closely related to physical property. ${ }^{179}$ In Starrett Housing, the tribunal noted with approval that the claimants "rely on precedents in international law in which cases measures of expropriation or taking, primarily aimed at physical property, have been deemed to comprise also rights of a contractual nature closely related to the physical property." 180 The Phelps Dodge International Corp. tribunal declined to find expropriation of the claimant's contractual rights, because the link with shares was insufficiently direct. ${ }^{181}$

As a matter of fact, expropriations often concern contractual rights closely associated with physical property. Nevertheless, although sovereign bonds would fail to meet a requirement for an association with physical property, the legal authority for such a requirement is tenuous. Two mixed-commission cases dealing with sovereign bonds do suggest, however, a distinction between physical and intangible assets; jurisdiction was found only for those sovereign bonds used for public works or services rendered to the government, as opposed to those issued for general budgetary purposes of the issuing country. In Companie Générale des Eaux de Caracas, the commission accepted jurisdiction over Venezuelan bearer bonds, issued to the Belgian claimant CGE, to finance public works. The direct link between bonds issued as payment for property transferred and services rendered to the government overcame the presumption of no

\footnotetext{
${ }^{176}$ For overviews, see W. Michael Reisman \& Robert D. Sloane, Indirect Expropriation and Its Valuation in the BIT Generation, 2004 BRIT. Y.B. INT'L L. 115; Schreuer, supra note 110; August Reinisch, Expropriation, in THE OXFORD HANDBOOK OF INTERNATIONAL INVESTMENT LAW (Peter Muchlinksi et al. eds., forthcoming 2008).

177 According to Higgins, "Sometimes rights that might seem more naturally to fall under the category of contract rights are treated as property." Rosalyn Higgins, The Taking of Property by the State: Recent Developments in International Law, 176 RECUEIL DES COURS 259, 271 (1982 III). Similarly, Sacerdoti, supra note 76, at 381, notes that "[a]ll rights and interests having an economic content come into play, including immaterial and contractual rights."

${ }^{178}$ Ernst H. Feilchenfeld, Rights and Remedies of Holders of Foreign Bonds, in 2 BONDS AND BONDHOLDERS, RIGHTS AND REMEDIES 130, 203 (Silvester E. Quindry ed., 1934).

${ }^{179}$ Of course, these awards have no binding effect on ICSID tribunals, though they might find the awards' reasoning persuasive or infer state practice. ICSID tribunals have certainly relied on non-ICSID awards in the past. See, for example, the Woodruff case, see supra note 136 and accompanying text. A nexus to physical property, however, seems to be the exception rather than the rule. See Bayindir Insaat Turizm Ticaret Ve Sanayi A.S. v. Islamic Republic of Pakistan, ICSID Case No. ARB/03/29, Jurisdiction, para. 255 (Nov. 14, 2005).

${ }^{180}$ Starrett Housing Corp. v. Islamic Republic of Iran, 4 Iran-U.S. Cl. Trib. Rep. 122, 156 (1983 III) (emphasis added).

${ }^{181}$ Phelps Dodge International Corp. v. Islamic Republic of Iran, 10 Iran-U.S. Cl. Trib. Rep. 157, 170 (1986 I).
} 
jurisdiction. ${ }^{182}$ In Boccardo, the commission accepted jurisdiction where the claimant had received bonds in exchange for merchandise furnished. ${ }^{183}$

Feilchenfeld and Borchard are among the few leading scholars who have examined the international law of public debt in detail. Their views on whether sovereign bonds may be expropriated diverge sharply. Feilchenfeld affirmed such protection. Borchard, by contrast, reserved a "distinct branch[] of the subject" for claims arising out of unpaid sovereign bonds held by the citizens of another country: "[Unpaid bonds] of the State differ in many respects from the contractual obligations arising out of a contract for concessions or the execution of public works." ${ }^{184}$ He called on arbitral tribunals to decline jurisdiction or to exercise more careful scrutiny than over ordinary contractual causes of action.

Bochard's reservation of a separate category for bonds relates back to the fourth typical feature of an "investment": the association with a commercial undertaking. In this vein, Schreuer highlighted that the "law of expropriation proceeds not from a traditional concept of tangible property but from a broad concept of economic rights that are necessary for the investor to pursue its business successfully." 185 Similarly, Wälde and Kolo wrote that "the key function of property is less the tangibility of 'things', but rather the capability of a combination of rights in a commercial and corporate setting and under a regulatory regime to earn a commercial rate of return." ${ }^{186}$ In this context, modern sovereign bonds are commercial instruments associated with no bundle of rights that would constitute a business venture.

In light of these considerations, it remains to be seen whether ICSID tribunals would qualify sovereign bonds as contractual rights subject to expropriation. Turning away from that threshold question, the following paragraphs deal with the constitutive elements of expropriation.

Despite the broad scope for expropriation, not every type of act resulting in economic loss to the investor amounts to expropriation. Only state acts are susceptible of constituting expropriation, ${ }^{187}$ and the specific characterization depends thus on whether the state slips into its commercial or sovereign shoes. ${ }^{188}$

${ }^{182}$ Compagnie Générale des Eaux de Caracas [Belgian Waterworks] v. Venezuela (1903), in THE LAW AND PROCEDURE OF INTERNATIONAL TRIBUNALS, supra note 112, at 78.

${ }^{183}$ Boccardo v. Venezuela (1903), in THE LAW AND PROCEDURE OF INTERNATIONAL TRIBUNALS, supra note 112 , at 80 .

${ }^{184}$ Edwin M. Borchard, Contractual Claims in International Law, 13 COLUM. L. REV. 457, 460, 476 (1913). The other two categories are (1) claims arising out of contracts between nationals of different countries, and (2) claims arising out of contracts between the a citizen abroad and a foreign government. Similarly, Luis Drago noted in State Loans in Their Relation to International Policy, 1 AJIL 692, 695 (1907), that sovereign bonds are "issued by virtue of the sovereign power of the state, as is its currency." For opposing view (rejecting the distinction promulgated by Borchard), see Aspinwall v. Venezuela (1885), in MOORE, supra note 30, at 3651; D. P. O'CONNELL, STATE SUCCESSION IN MUNICIPAL LAW AND INTERNATIONAL LAW 189 (1967); WILLIAM EDWARD HALL, INTERNATIONAL LAW (6th ed. 1909), at 276 ("Fundamentally, . . there is no difference in principle between wrongs inflicted by breach of a monetary agreement and other wrongs for which the state, as itself the wrongdoer, is immediately responsible."). See also the rejection of various "responsibilit[ies] of states" in Russia v. Turkey (Russian Indemnity), Hague Ct. Rep. (Scott) 298 (Perm. Ct. Arb. 1912), 7 AJIL 178, 188 (1913).

${ }^{185}$ Schreuer, supra note 110, at 24 (emphasis added); Ursula Kriebaum \& Christoph Schreuer, The Concept of Property in Human Rights Law and International Investment Law, in HUMAN RIGHTS DEMOCRACY AND THE RULE OF LAW: Liber Amicorum LuZiUS Wildhaber 743, 757 (Stephan Breitenmoser et al. eds., 2007).

${ }^{186}$ Waelde \& Kolo, supra note 110, at 835 (emphasis added).

${ }^{187}$ Consortium R.F.C.C. v. Kingdom of Morocco, ICSID Case No. ARB/00/6, Award, para. 65 (Dec. 22, 2003).

${ }^{188}$ For example, in Jalapa Railroad \& Power Co., (U.S. v. Mex.) (U.S.-Mex. Mixed Cl. Comm'n 1948), in 8 WHITEMAN, DIGEST OF INTERNATIONAL LAW 908 (1967), Am.-Mex. Cl. Rep. 538, 540 (1948), the commission held that a legislative act declaring a particular clause in a contract null and void could not be interpreted as 
The restriction to state acts suggests the following analysis. Could a private corporation have successfully carried out a similar restructuring implemented by a country? In other words, did the government use specific regulatory, administrative, or governmental powers in its sovereign bond exchange? Consortium R.F.C.C. v. Morocco held that only unilateral measures taken specifically as an exercise of public authority could give rise to expropriation. A host state acting as a contractual party does not interfere with the normal exercise of the investors' rights, but rather fails to perform the contract. ${ }^{189}$ Lack of performance does not amount to a treaty breach unless it is proven that the state has gone beyond its role as a mere party to the contract and has exercised the specific functions of a sovereign authority. ${ }^{190}$

Traditionally, a measure's being in the public interest and nondiscriminatory was relevant only to its legality or illegality, not to whether it amounted to an expropriation. ${ }^{191}$ A recent tendency is to regard the lack of public interest and the presence of discrimination as constitutive elements of expropriation, rather than as justifying an expropriatory measure. ${ }^{192}$ Under this approach, if the exercise of governmental powers is both in the public interest and nondiscriminatory, the act in question would not be considered an expropriation, with the consequence that no compensation was due on that basis. ${ }^{193}$ In national economic emergencies the legitimate scope of governmental measures in the public interest might be greater; hence, economic policy measures adopted in response to financial crises would need to rise to a higher level of intensity to constitute expropriation.

The effect of the act on the investor is another element relevant to expropriation. The case law does not consider a mere default to be expropriation. For example, Waste Management $v$. Mexico found that the City of Acapulco's failure to pay fees due under a concession contract did not amount to indirect expropriation. ${ }^{194}$ Even though the investor had lost some of its benefits, it had at all times retained the control and use of its property: "The mere non-performance of contractual obligations is not to be equated with a taking of property, nor (unless accompanied by other elements) is tantamount to expropriation. Any private party can fail to perform its contracts, whereas nationalization and expropriation are inherently governmental acts." 195 The tribunal observed that a "failing enterprise is not expropriated just because debts are not paid or other contractual obligations are not fulfilled." ${ }^{196}$

an ordinary breach of contract; rather, the government stepped out of its role as contracting party and, by exercising its sovereign powers, sought to excape its obligations under the contract. To the same effect, see Impregilo S.p.A. v. Islamic Republic of Pakistan, ICSID Case No. ARB/03/3, Jurisdiction, para. 261 (Apr. 22, 2005).

${ }^{189}$ Consortium R.F.C.C. (quoted approvingly in Impregilo, para. 278).

${ }^{190}$ Impregilo, para. 276.

191 Schreuer, supra note 110 , at 1-2.

192 This argument was accepted in Methanex Corp. v. United States, Final Award, para. 3 (NAFTA Ch. 11 Arb. Trib. Aug. 3, 2005); see Saluka Partial Award, supra note 98, para. 263.

${ }^{193}$ On state responsibility in general, see Stephen M. Schwebel, On Whether the Breach by a State of a Contract with an Alien Is a Breach of International Law, in JUSTICE IN INTERNATIONAL LAW: SELECTED WRITINGS OF STEPHEN M. SCHWEBEL 425, 434 (1994): “[A] State is responsible under international law if it commits not any breach, but an arbitrary breach, of a contract between that State and an alien. What is 'arbitrary'? It is a breach 'for governmental rather than commercial reasons."

${ }^{194}$ Waste Management, Inc. v. United Mexican States, ICSID Case No. ARB(AF)/00/3, Award (Apr. 30, 2004) [hereinafter Waste Management Award].

${ }^{195}$ Id., para. 174.

${ }^{196}$ Id., para. 177. 
In the Olguin case, the claimant had purchased "investment bonds" (certificates of deposit endorsed by a state agency) on which the state subsequently defaulted. ${ }^{197}$ In refusing to characterize the default as expropriation, the tribunal noted that the situation merely involved a business loss due to a financial crisis; for expropriation, a teleologically driven action (intent) was required. ${ }^{198}$ This condition is unusual in ICSID case law. Schreuer noted that the "context suggests that the Tribunal's point was that mere nonpayment of a debt does not constitute an expropriation. ... [I]t is also possible that what the Tribunal meant was simply that there had to be some positive action rather than a mere omission." ${ }^{199}$

There are other cases to much the same effect. In SGS v. Philippines, which concerned claims for outstanding payments, the tribunal held that a "mere refusal to pay a debt is not an expropriation of property, at least where remedies exist in respect of such a refusal." ${ }^{200}$ In $C M S v$. Argentina, the claim of expropriation was rejected since CMS had retained "full ownership and control" over its shares in Transportadora de Gas del Norte, notwithstanding their diminished value. ${ }^{201}$ As far back as 1868 , the U.S.-Mexico Claims Commission held that the failure to fulfill the obligations of a bond issued for supplies was not an "injury to . . property." ${ }^{202}$ This line of cases suggests that a default on a sovereign bond does not qualify as expropriation, because it does not extinguish the bondholder's rights under the bond.

There is hence ample authority that failure to pay a sovereign bond does not engage the state's international responsibility, even if it constitutes a default under the bond. ${ }^{203}$ If governments act as arm's-length contract parties, there can be no expropriation. Feilchenfeld highlighted this crucial caveat:

[A]s international law stands to-day, a debtor state commits an international delinquency by annihilating a debt entirely through repudiation, confiscation, of virtual destruction (interference with the substance of the debt), but . . . international law has not yet reached the point where all lesser acts causing defaults and damage to creditors give rise to legal protests based on international law. ${ }^{204}$

Argentina's debt restructuring might go beyond mere default. Ley 26017, which prohibits reopening the debt restructuring, is most certainly a state act that interfered with existing contractual rights, independently of whether the default, as well as other restructuring measures, had been private. ${ }^{205}$ The key question is whether Ley 26017 was incidental to the sovereign

197 Olguín Award, supra note 96.

${ }^{198}$ Id., para. 84 (unofficial ICSID translation): "Expropriation therefore requires a teleologically driven action for it to occur; omissions, however egregious they may be, are not sufficient for it to take place."

${ }^{199}$ Schreuer, supra note 110, para. 118.

${ }^{200}$ SGS-Philippines Jurisdiction Award, supra note 50, para. 161: "Whatever debt the Philippines may owe to SGS still exists; whatever right to interest for late payment SGS had it still has. There has been no law or decree enacted by the Philippines attempting to expropriate or annul the debt, nor any action tantamount to an expropriation."

${ }^{201}$ CMS Award, supra note 38, paras. 263-64.

202 J. A. Manasse \& Co. v. Mexico (1868), in MOORE, supra note 30, at 3462, 3463.

${ }^{203}$ See supra note 133 and accompanying text. Contra Fedax N.V. v. Republic of Venezuela, ICSID Case No. ARB/96/3, Final Award, para. 29 (Mar. 9, 1998), 5 ICSID REP. 200 (2002), 37 ILM 1391 (1998). Venezuela is bound under international law to pay the promissory notes when due.

${ }^{204}$ Feilchenfeld, supra note 178 , at 170.

${ }^{205}$ See supra note 18 for some background on this law. 
debt restructuring and served primarily as a means to enhance the credibility of the exchange offer or, alternatively, whether that legislative act aimed directly at abrogating the rights of uncooperative bondholders.

Forceful restructuring measures could constitute expropriation. ${ }^{206}$ Ley 26017 could thus be coercive. Repudiation of sovereign bonds would amount to expropriation, as it aims at extinguishing bondholders' claims permanently. ${ }^{207}$ In this vein, Lauder v. Czech Republic affirmed that effective neutralization of the enjoyment of property amounts to indirect expropriation. ${ }^{208}$ Postponing payment indefinitely, such as a declaration or legislation never to service a particular series of bonds in the future, could constitute expropriation. ${ }^{209}$ Ley 26017 did not, however, declare that an entire series of bonds would never be serviced. The law functioned, instead, as an incentive device to encourage participation in the bond exchange, which purposefully discriminated against those bondholders who considered a holdout strategy. Traditionally, international law frowns upon discrimination by nationality, and such discrimination would automatically trigger internationally liability. Ley 26017, however, is a discriminatory measure of a very different kind. That discrimination is directed against holdout creditors. Whether this particular form of discrimination violates international law depends on whether international law requires countries to treat all creditors equally. It is at least doubtful, however, that international law incorporates such a general equal treatment obligation, over and above an obligation not to discriminate against creditors by nationality. The better view is that restructuring measures trigger international liability only insofar as this type of discrimination becomes coercive. ${ }^{210}$

In case expropriation is to no avail, the treaty obligation of fair and equitable treatment could be a promising avenue for holders of Argentine bonds. The following, concise review will focus on the most germane aspects of the case law on this treatment standard, while leaving other important issues (such as the international minimum standard of treatment) unaddressed. ${ }^{211}$

\footnotetext{
${ }^{206}$ All private debt restructurings — in the corporate and the sovereign context—rely to some extent on incentives to keep in creditors who consider a holdout strategy. The key question is when such incentive devices become coercive. In assessing coerciveness, it would be reasonable to take into account limited possibilities of enforcement against sovereigns, as well as the absence of restructuring alternatives for countries.

207 See Certain Norwegian Loans (Fr. v. Nor.), 1957 ICJ REP. 9 (July 6). In dissent, id. at 90, Judge Read cited the French position that sovereign bonds issued abroad "cannot be repudiated without giving rise to a breach of international law."

${ }^{208}$ Lauder v. Czech Republic, Final Award, para. 200 (UNCITRAL Arb. Trib. Sept. 3, 2001), at <http://ita. law.uvic.ca/documents/LauderAward.pdf $>$. See Metalclad Corp. v. United Mexican States, ICSID Case No. ARB(AF)/97/1, Award, para. 103 (Aug. 30, 2000), where the tribunal held that indirect expropriation takes place if "the effect of depriving the owner, in whole or in significant part, of the use or reasonably-to-be-expected economic benefits of property even if not necessarily to the obvious benefit of the host State."

209 "As long as the debt is omitted from the budget [, virtual destruction is] not treated differently from regular complete repudiation.” Feilchenfeld, supra note 178, at 205.

${ }^{210}$ All private debt restructurings - in the corporate and the sovereign context-rely to some extent on incentives to bind in creditors who consider a holdout strategy. The key question is when such incentive devices become coercive. In assessing coerciveness, it would be reasonable to take into account limited possibilities of enforcement against sovereigns as well as the absence of restructuring alternatives for countries.

211 See Christoph Schreuer, Fair and Equitable Treatment in Arbitral Practice, 6 J. WORLD INVESTMENT \& TRADE 357, 360-67 (2005) (highlighting variation in linkage to customary law); Catherine Yannaca-Small, Fair and Equitable Treatment Standard in International Investment Law, in INTERNATIONAL INVESTMENT LAW: A CHANGING LANDSCAPE 73, 81-103 (OECD ed., 2005). IOANA TUDOR, THE FAIR AND EQUITABLE TREATMENT STANDARD IN INTERNATIONAL FOREIGN INVESTMENT LAW (forthcoming 2008) comprehensively covers the case law on fair and equitable treatment.
} 


\section{Fair and Equitable Treatment}

The inclusion of a fair and equitable treatment obligation is a regular feature in newer BITs. Nevertheless, due to its level of abstraction, the standard is surrounded by considerable fog. More than for other treatment standards, the particular circumstances of each case shape its interpretation. In this sense, it is relative. Judicial decisions that identify typical fact situations therefore play a central role. ${ }^{212}$ From the case law, Schreuer identified four typical fact situations: (1) transparency and the protection of the investor's legitimate expectations, (2) freedom from coercion and harassment, (3) procedural propriety and due process, and (4) good faith.

In contrast to the MFN and national treatment standards, the fair and equitable treatment standard is independent of other nationals' treatment. Discrimination is therefore no precondition for breach. The next six paragraphs provide a brief overview of the case law on fair and equitable treatment.

In the ELSI case, the International Court of Justice (ICJ) held that Palermo's mayor, by requisitioning the U.S.-owned company ELSI in response to its straight course toward insolvency, did not violate the clause in the 1948 U.S.-Italy Treaty of Friendship, Commerce and Navigation that prohibited arbitrary or discriminatory measures. Subsequent awards relied on ELSI's use of the principle of arbitrariness as a means of interpreting the fair and equitable standard: "Arbitrariness is not so much something opposed to a rule of law, as something opposed to the rule of law. . . . It is wilful disregard of due process of law, an act which shocks, or at least surprises, a sense of juridical propriety." 213

The ICSID tribunal in the Genin case refused to find a breach of the fair and equitable standard arising out of the Estonian Innovation Bank's purchase of an Estonian bank branch whose license had been withdrawn (subsequent to the purchase) because of alleged discrepancies in the branch's balance sheets. The test for breach of the standard was whether there were "acts showing a wilful neglect of duty, an insufficiency of action falling far below international standards, or even subjective bad faith." ${ }^{14}$ This test was not met in Genin since Estonia, despite an element of arbitrariness in removing the branch's license, had ample grounds to intervene to preserve the integrity of its banking system.

A series of cases decided by arbitral tribunals under Chapter 11 of the North American Free Trade Agreement (NAFTA) addresses the standard of fair and equitable treatment. In finding a violation of the standard, the tribunal in Pope \& Talbot lowered the threshold for a violation. It dispensed with the requirement that the alleged conduct be "'egregious,' 'outrageous' or 'shocking,' or otherwise extraordinary." ${ }^{215}$ Instead, the average observer's "surprise[] by what the government has done" is sufficient. ${ }^{216}$ As the tribunal itself recognized, this interpretation considerably expanded the scope of fair and equitable treatment.

${ }^{212}$ Schreuer, supra note 211, at 373-74.

${ }^{213}$ Elettronica Sicula S.p.A. (ELSI) (U.S. v. Italy), 1989 ICJ REP. 15, paras. 101, 128 (July 20).

${ }^{214}$ Genin v. Republic of Estonia, ICSID Case No. ARB/99/2, Award, para. 367 (June 25, 2001).

${ }^{215}$ Pope \& Talbot Inc. v. Canada, Phase 2, para. 118 (NAFTA Ch. 11 Arb. Trib. Apr. 10, 2001), 7 ICSID ReP. 102, available at $<$ http://ita.law.uvic.ca/documents/PopeandTalbot-Merit.pdf $>$.

${ }^{216}$ Pope \& Talbot Inc. v. Canada, Damages, para. 64 (NAFTA Ch. 11 Arb. Trib. May 31, 2002), 41 ILM 1347 (2002), available at $<$ http://ita.law.uvic.ca/documents/Pope-Damages.pdf $>$. To the same effect, see ADF Group Inc. v. United States, ICSID Case No. ARB(AF)/00/1, Award, paras. 179-86 (Jan. 9, 2003), 18 ICSID REV. 195 (2003), 6 ICSID REP. 470 (2004). 
The Mondev tribunal refined Pope \& Talbot's holding: "The test is not whether a particular result is surprising, but whether the shock or surprise occasioned to an impartial tribunal leads, on reflection, to justified concerns as to the judicial propriety of the outcome." The tribunal ought to decide "in the light of all the available facts" whether the governmental action was "clearly improper and discreditable." 217

In Loewen, the Canadian claimant alleged judicial improprieties in Mississippi state court. The tribunal found that a "decision which is in breach of municipal law and is discriminatory against the foreign litigant amounts to manifest injustice according to international law."218 Concurring with Pope \& Talbot, "bad faith or malicious intention" was not required. Rather, "Manifest injustice in the sense of a lack of due process leading to an outcome which offends a sense of judicial propriety" sufficed to find a breach. ${ }^{219}$ Emphasizing international law's concern with discriminatory breaches of municipal law, the tribunal held that manifest procedural improprieties tainted the state court's judgment. Hence, "the whole trial and its resultant verdict were clearly improper and discreditable."220

Waste Management established the principle that the fair and equitable standard is violated if conduct is

arbitrary, grossly unfair, unjust or idiosyncratic, is discriminatory and exposes the claimant to sectional or racial prejudice, or involves a lack of due process leading to an outcome which offends judicial propriety — as might be the case with a manifest failure of natural justice in judicial proceedings or a complete lack of transparency and candour in an administrative process. In applying the standard it is relevant that the treatment is in breach of representations made by the host State which were reasonably relied on by the claimant. $^{221}$

On the particular facts, the tribunal held that this test was not met. ${ }^{222}$

A leading ICSID case on the predictability of the investment framework in economic crises is CMS v. Argentina, in which the tribunal upheld CMS's claim for violation of the fair and equitable standard. The tribunal noted: "There can be no doubt . . . that a stable legal and business environment is an essential element of fair and equitable treatment." And in this particular case, the measures complained of "did in fact entirely transform and alter the legal and business environment under which the investment was decided and made."223

The CMS tribunal did not require bad faith for violation of the standard. ${ }^{224}$ What is problematic, however, is the tribunal's view that fair and equitable treatment is an "objective requirement" unrelated to the reasons for the challenged measures. ${ }^{225}$ This conception is at

\footnotetext{
${ }^{217}$ Mondev International Ltd. v. United States, ICSCID No. ARB(AF)/99/2, Award, para. 127 (Oct. 11, 2002), 6 ICSID REP. 192 (2004), 42 ILM 85 (2003) (quoted approvingly in Loewen Group, Inc. v. United States, ICSID Case No. ARB(AF)/98/3, Award, para. 133 (June 26, 2003), 7 ICSID REP. 442 (2005), 42 ILM 811 (2003)).

${ }^{218}$ Loewen Group, para. 135.

${ }^{219}$ Id., para. 132.

${ }^{220}$ Id., para. 137.

221 Waste Management Award, supra note 194, para. 98.

${ }^{222}$ Id., para. 140.

${ }^{223}$ CMS Award, supra note 38, paras. 274-75.

${ }^{224} I d$., paras. 274, 281, 284.

${ }^{225}$ Id., para. 280.
} 
odds with the requirement to examine such an abstract standard in light of the particular circumstances of the case. In Lauder, by contrast, the UNCITRAL tribunal rightly asserted that the standard is subjective and depends heavily on factual context. ${ }^{226}$

Noble Ventures, Inc. v. Romania adopted a different approach. The claimant alleged a breach of the fair and equitable standard because the respondent had initiated the reorganization of the Romanian company Combinatul Siderurgic Resita (CSR). The ICSID tribunal held that "it is difficult to regard either the initiation or the conduct of the judicial proceedings as arbitrary," because CRS was insolvent at the time. In addition, there was no "prospect of . . rescheduling debts. ... Such proceedings are provided for in all legal systems and for much the same reasons. ... [T] hey were initiated and conducted according to the law . . . CSR was in a situation that would have justified the initiation of comparable proceedings in most other countries. Arbitrariness is therefore excluded."227

In refining the fair and equitable standard, the tribunal in Noble Ventures highlighted the universality of municipal insolvency laws. Recourse to municipal law thus helps to construe the meaning of fair and equitable treatment. By definition, the invocation of a legal procedure that exists in virtually all legal systems cannot be arbitrary. This mode of analysis follows the tradition of private law analogies in international law, pioneered by H. Lauterpacht. ${ }^{228}$ Similar to the finding in Noble Ventures, if ICSID tribunals readily characterized sovereign debt restructurings initiated by countries in genuine financial distress as arbitrary, the tribunals would be disregarding the generally recognized principle of municipal law that financial distress requires a balancing of creditor and debtor interests. International tribunals owe deference to this common feature, notwithstanding some variations, of municipal insolvency laws.

The UN Conference on Trade and Development endorsed a methodology akin to private law analogies as a means of clarifying fair and equitable treatment: "[I]t is possible to identify certain forms of behaviour that appear to be contrary to fairness and equity in most legal systems and to extrapolate from this the type of State action that may be inconsistent with fair and equitable treatment, using the plain meaning approach." Accordingly, fraudulent acts, capricious discrimination against foreign investors, and unjust enrichment of the state could violate the standard. ${ }^{229}$

In summary, the fair and equitable treatment standard, as developed in the case law, protects legitimate commercial expectations. Though the original focus of the standard was on procedure, it has gradually expanded into the substantive realm. The current standard is that governmental acts need to conform to international standards of transparency, nonarbitrariness, due process, and proportionality to the policy aims involved. The newer case law dispenses with the requirement of bad faith. Nevertheless, the case law largely leaves open the question as to the source of the evolving substantive elements of fair and equitable treatment. This indeterminacy leaves the standard only loosely defined and undermines legal certainty.

\footnotetext{
${ }^{226}$ Lauder v. Czech Republic, Final Award, para. 292 (UNCITRAL Arb. Trib. Sept. 3, 2001), at < http://ita. law.uvic.ca/documents/LauderAward.pdf $>$.

${ }^{227}$ Noble Ventures, Inc. v. Romania, ICSID Case No. ARB/01/11, Award, paras. 177-78 (Oct. 12, 2005), at $<$ http://ita.law.uvic.ca/documents/Noble.pdf $>$.

${ }^{228}$ LAUTERPACHT, supra note 152.

${ }^{229}$ UNCTAD, Fair and Equitable Treatment, UN Doc. UNCTAD/ITE/IIT/11, Vol. III, at 12 (1999).
} 
It risks becoming a fallback standard that can be invoked — as the ultimate safety net for investors-whenever the requirements of all other standards are not met. Noble Ventures, where the content of fair and equitable standard is informed by municipal law, suggests the way forward.

What do these cases mean for sovereign bondholders? The fair and equitable standard could, in practical terms, elevate nonperformance of contractual obligations into treaty breaches. ${ }^{230}$ Could a sovereign bond default per se breach the standard? The preponderance of the limited case law on this question would reject such de facto elevation. An incidental remark by the ad hoc annulment committee ${ }^{231}$ in Vivendi v. Argentina suggests as much: "It may be that 'mere' breaches of contract, unaccompanied by bad faith or other aggravating circumstances, will rarely amount to a breach of the fair and equitable treatment standard." ${ }^{232}$

In Waste Management the tribunal held that Acapulco did not act arbitrarily since the city found itself in a situation of genuine difficulty: "the persistent non-payment of debts by a municipality is not to be equated with a violation of Article 1105 [fair and equitable treatment], provided that it does not amount to an outright and unjustified repudiation of the transaction and provided that some remedy is open to the creditor to address the problem." 233 Similarly, nonparticipating bondholders have the remedy of bringing suit in municipal court.

There is also authority for the opposite view. The tribunal in Mondev suggested that contractual breaches generally violate the fair and equitable standard. ${ }^{234}$ The SGS $v$. Philippines decision on jurisdiction left open that possibility. In an offhand remark on the merits, the tribunal suggested that "an unjustified refusal to pay sums admittedly payable under an award or a contract at least raises arguable issues under Article IV [fair and equitable treatment]." 235

Given this limited authority, Schreuer argued that a simple breach of contract is part of normal business risk and does not violate the fair and equitable standard. Willful refusal to abide by contractual obligations, abuse of government authority, and bad faith in the course of contractual performance could well lead to breach. Yet "a breach of contract resulting from serious difficulties on the part of the government to comply with its financial obligations cannot be equated with unfair and inequitable treatment." ${ }^{236}$ This statement suggests that a sovereign default, provided it was motivated by serious financial difficulties, does not violate the standard.

Even if a default on the sovereign bond does not violate the fair and equitable treatment standard, the implementation of the sovereign debt restructuring could. Corporations in financial distress frequently use bond exchanges. This technique has migrated into the sovereign bond context and become a generally accepted method of restructuring countries' unsustainable debt burden. In some respects, sovereign bond exchanges are intended to avoid breaching legal obligations under the extant bonds (or further breaches where the bonds are already in default).

${ }^{230}$ Schreuer, supra note 211 , at 379.

${ }^{231}$ ICSID Convention, supra note 28, Art. 52. ICSID tribunals' final awards may be challenged before an ad hoc committee that has the power to annul the award in certain narrow circumstances (for example, improper constitution of the tribunal, manifest excess of power, corruption of a member of the tribunal, serious departure fom a fundamental rule of procedure).

${ }^{232}$ Vivendi Annulment Decision, supra note 136, para. 101 n.73.

${ }^{233}$ Waste Management Award, supra note 194, para. 115.

${ }^{234}$ Mondev v. United States, ICSCID No. ARB(AF)/99/2, Award, para. 98 (Oct. 11, 2002), 6 ICSID REP. 192 (2004), 42 ILM 85 (2003).

${ }^{235}$ SGS-Philippines Jurisdiction Award, supra note 50, para. 162.

${ }^{236}$ Schreuer, supra note 211 , at 380. 
The Argentine bond exchange in 2005 employed this common financial restructuring technique. The following paragraphs examine, with special application to the Argentine debt crisis, six possible justifications for claiming that such a restructuring violates the fair and equitable standard.

First, bondholders might allege that the process of elaborating the bond exchange lacked transparency, undermining their legitimate expectations. ${ }^{237}$ Transparency enables investors to adapt their business decisions in advance and to comply with the investment framework. Schreuer explained that " $\mathrm{t}]$ ransparency means that the legal framework for the investor's operations is readily apparent and that any decisions affecting the investor can be traced to that legal framework." 238

For sovereign bonds, such a transparency argument is unlikely to succeed. Complex exchanges involving multiple bond series, as well as several currencies and governing laws, require time to design and implement. Argentina set forth the terms and conditions of its exchange offer in detail. While the exchange was offered pursuant to SEC requirements, bondholders might allege that Argentina was never transparent about its payment capacity, which remained shrouded in secrecy. This particular lack of transparency could be a basis for a violation of the fair and equitable treatment standard. Perhaps so, but it is unlikely that Argentine bondholders would have formed a legally protected expectation that Argentina would never carry out a sovereign debt restructuring. The country had restructured its external debt on several occasions in the past (as have many other middle-income countries, in Latin America and beyond), and it had made no assurances, and thereby created expectations, that it would not seek to restructure its debts in the wake of a sovereign debt default.

Second, coercion is a potential source of a claim for fair and equitable treatment. Aggressive sovereign debt exchanges could trigger BIT liability. The existing case law on coercion is sparse. The Pope \& Talbot tribunal found that a regulatory verification that involved "threats and misrepresentations" and was "burdensome and confrontational" violated the fair and equitable standard. ${ }^{239}$ In Tecmed, the tribunal held that a refusal to renew a license-designed to force the investor to relocate-also violated the standard. ${ }^{240}$ Bond exchanges are unlikely to violate that standard, however, unless clearly coercive. It would fall upon the claimant to prove elements of coercion in the exchange. As the fundamental basis for claiming a coercive exchange could be contractual, recourse to municipal law might be necessary.

Third, bondholders could take the view that the take-it-or-leave-it exchange offer violated due process. They might assert that the Argentine government did not hear their concerns prior to the elaboration of the final proposal. They could argue that the government adopted a confrontational attitude and did not engage in serious restructuring negotiations. Instead, it arguably opted for unilateral action.

${ }^{237}$ Metalclad Corp. v. United Mexican States, ICSID Case No. ARB(AF)/97/1, Award, paras. 76, 89 (Aug. 30, 2000) (affirming a violation of fair and equitable treatment on this ground); see Maffezini Award, supra note 165, para. 83; CME Czech Republic B.V.v. Czech Republic, Partial Award, para. 611 (UNCITRAL Arb. Trib. Sept. 13, 2001), at <http://ita.law.uvic.ca/documents/CME-2001PartialAward.pdf>; Tecmed Award, supra note 168, para. 152.

${ }^{238}$ Schreuer, supra note 211 , at 374 .

${ }^{239}$ Pope \& Talbot Inc. v. Canada, Damages, paras. 68-69 (NAFTA Ch. 11 Arb. Trib. May 31, 2002), 41 ILM 1347 (2002), available at $<$ http://ita.law.uvic.ca/documents/Pope-Damages.pdf $>$.

240 Tecmed Award, supra note 168. 
A violation of due process requires that investors' legitimate expectations with respect to the restructuring be disappointed. A government that had at least attempted to restructure its debt obligations consensually and in good faith with a majority of bondholders is likely to fulfill such expectations. At the other extreme, an obligation to engage in potentially lengthy renegotiations when agreement is elusive and when anonymous bondholders are widely dispersed could well be considered unduly burdensome on governments in financial distress.

Fourth, one might argue that the restructuring itself itself was not carried out in good faith. While the bona fide principle is well recognized in international law, assessing whether a specific debt restructuring was carried out in good faith, given the economic circumstances at the time, is complex and requires a detailed examination of the country's payment capacity. A tribunal could not avoid addressing this question. In order to demonstrate the government's bad faith in carrying out the restructuring, bondholders would have to show that the government's unwillingness to pay prompted the restructuring.

Fifth, bondholders could potentially assert a profound transformation of the business environment à la $C M S$, but it would require logical gymnastics to be able to speak of a "business environment" for sovereign bonds. ${ }^{241}$ The only conceivable business environment is the entire national economy. To guarantee the stability of this business environment would amount to an impossible promise. Sovereign bonds are general purpose financial instruments, a voluntary alternative to taxation as a means of raising funds for the public treasury. Sovereign bonds are free standing. They do not exist in a business environment.

Sixth, one might argue that the restructuring undermined the legal framework of the sovereign bonds. The legal framework for the typical commercial sovereign bond, however, is a third country's municipal law_a framework over which the debtor country has no control. The law applicable to the bond is outside its reach and remains unchanged. It is therefore difficult to think of measures for restructuring that would affect the stability of the legal framework directly.

Does Ley $26017^{242}$ sufficiently affect that legal framework? Encouraging participation in the exchange might well have been the primary motivation. In that case, the law would serve as a commitment device, underpinning the promise that the first offer will be the final one. Without the law, the exchange might have failed to achieve a high level of bondholder participation. This way of understanding the measure could indicate that the measure was proportionate to the policy aim involved. Nevertheless, Ley 26017 could violate the fair and equitable standard if the law's primary purpose was to abrogate the rights of nonparticipating bondholders.

An assessment of fair and equitable treatment must take a large number of factual elements into account. A central element is that sovereign debt exchanges serve, in part, as a substitute for the lack of statutory mechanisms for sovereign debt restructurings. Bond exchanges are the only viable method for a country — versus a corporation — to restructure an unsustainable debt burden. Incentive features are often critical to the success of a bond exchange. They partially substitute for cramdown powers in insolvency_-an accepted element of municipal insolvency

\footnotetext{
241 The need for such gymnastics is not surprising, given the discussion in part I on why sovereign bonds are unlikely to qualify as "investment" for lack of association with a commercial undertaking.

242 The law prevents an improved offer to nonparticipating creditors. See supra note 18.
} 
law. Unless the use of a bond exchange manifestly discriminates against a minority that is holding out, ICSID tribunals ought to leave considerable leeway to countries in designing their sovereign debt restructurings.

Despite its being a legal principle, the plain meaning of the fair and equitable standard leaves considerable discretion to arbiters in considering just what is equitable. It is a unique treatment standard in that it allows tribunals to perform a comprehensive judicial balancing of investors' and host states' legally protected interests. For sovereign bonds in default, there is thus scope to deny liability if the contrary outcome would be unduly harsh for a country incapable of repaying all its debts. An alternative is to limit the quantum of liability if the country is incapable of repaying all its sovereign bonds.

The next part focuses on the quantum of compensation due. It shows why the legally protected expectation under the four treatment standards is unlikely to correspond to the bond's full face value.

\section{COMPENSATION ON SOVEREIGN BONDS}

BITs generally prescribe prompt, adequate, and effective compensation. ${ }^{243}$ Yet the peculiarities of sovereign bonds traded on secondary markets might warrant a departure from this principle.

International courts and tribunals have repeatedly stressed that property rights and investment protection are no insurance against ordinary commercial risks. ${ }^{244}$ In the words of the Maffezini and CMS tribunals: "Bilateral Investment Treaties are not insurance policies against bad business judgments." ${ }^{245}$ In Starrett Housing, the Iran-U.S. Claims Tribunal held that "investors in Iran, like investors in all other countries, have to assume a risk that the country might experience strikes, lockouts, disturbances, changes of the economic and political system and even revolution. . . A revolution as such does not as such entitle investors to compensation under international law." ${ }^{246}$ Similarly, the Saluka tribunal, noting the "serious risks to investing in IPB [a Czech bank]," declined to find an expropriation. ${ }^{247}$

Similar considerations apply to sovereign debt crises. BIT protection is no insurance device against default risk on sovereign bonds. ${ }^{248}$ For purposes of ICSID arbitration, the investor buys with notice of the risks, weighing the probabilities of large profits against the danger of a full or partial loss of principal and interest. A bondholder has no assurances that she will be paid in all states of the world. Seventy-five years ago, Feilchenfeld eloquently captured the

${ }^{243}$ For this "Hull" formula, see SORNARAJAH, supra note 59, at 242-46. Adequacy refers to fair market value. On this notion, see Irmgard Marboe, Compensation and Damages in International Law, $7 \mathrm{~J}$. WORLD INVESTMENT \& Trade 723 (2006). See also AGIP S.p.A. v. People's Republic of the Congo, Award, ICSID Case No. ARB/77/1, Award (Nov. 30, 1979), 1 ICSID Rep. 306, 322 (1993); Liberian Eastern Timber Corp. v. Republic of Liberia, ICSID Case No. ARB/83/2, Award (Mar. 31, 1986), 2 ICSID REP. 346 (1994), 26 ILM 647 (1987).

${ }^{244}$ Reinisch, supra note 176.

245 Maffezini Award, supra note 165, para. 64; CMS Gas Transmission Co. v. Argentine Repubic, ICSID Case No. Arb/01/8, Objections to Jurisdiction, para. 29 (July 17, 2003); CMS Award, supra note 38, para. 244.

246 Starrett Housing Corp. v. Islamic Republic of Iran, 4 Iran-U.S. Cl. Trib. Rep. 122, 156 (1983 III).

247 Saluka Partial Award, supra note 98, paras. 55, 275; see Generation Ukraine Inc. v. Ukraine, ICSID Case No. ARB/00/9, Award, para. 20.37 (Sept. 16, 2003), 44 ILM 404 (2005).

${ }^{248}$ For insightful analysis on general risk allocation in international investment law, see William W. Burke-White \& Andreas Von Staden, Investment Protection in Extraordinary Times: The Interpretation and Application of Nonprecluded Measures Provisions in Bilateral Investment Treaties, 48 VA. J. INT'L L. (forthcoming 2008). 
philosophy of bondholder protection under international law: "Generally speaking, it might be said that international law will guarantee to the creditor the existence of a debt and of a debtor, but not the existence of a good debt and of a rich debtor." ${ }^{249}$ The time-honored principle that international law ought not to affect the risk distribution in sovereign debt instruments ex post still stands.

Even relatively carefree investors cannot fail to notice the lack of efficacy in the legal protection of sovereign bondholders. Bond prospectuses contain detailed disclaimers on risk factors. The relatively high interest rate payable on bonds issued by some developing countries is another indicator that the bond purchases involve significant risks. ${ }^{250}$ Realistic expectations on debt instruments trade off high risk against high return. By judicially curing this fundamental deficiency in creditor protection ex post, courts and international tribunals could create creditor moral hazard. ${ }^{251}$ Repayment of sovereign bonds, even for those with high default risk ex ante, could effectively be guaranteed. ICSID awards ought not to affect the relative risk properties of various sovereign bonds. Bondholders bear the risk of deteriorating sovereign creditworthiness.

International investment laws protect against frustration of legitimate expectations. ${ }^{252}$ Favorable macroeconomic conditions are transient, particularly in developing countries, and are subject to inevitable swings in market value. Echoing the Chinn case, ${ }^{253}$ bondholders, like other creditors, cannot expect to be isolated from financial crises and subsequent sovereign debt restructurings. The reasonable bondholder would have contemplated a full range of possible states of the world. In some, she is going to pocket a sizable profit, in others a small loss, and in some a substantial loss.

In the Kearney case before the U.S.-Mexican General Claims Commission, the umpire held in this spirit: "He [the claimant] entered into the contract of his own accord, fully aware of the condition of the Republic of Mexico and of its ability or otherwise to pay its debts, and trusted to the good faith of the Mexican government." ${ }^{254}$ The commission well recognized that the bondholder enters such a contract voluntarily, contemplating the up- and downside risks.

${ }^{249}$ ERnst H. FEILCHENFEld, PUbliC DebTS AND STATE SUCCESSION 657 (1931).

${ }^{250}$ Default risk on a bond is different from the risk sharing that is typical of investments within Article 25 of the ICSID Convention. On this typical element, see supra text accompanying notes 102-03. Risks of the transaction may be held against the investor.

251 "Creditor moral hazard" refers to the phenomenon in which an implicit repayment guarantee by a third party (the executive, the courts, or an international institution such as the International Monetary Fund) to creditors modifies the relative risk properties of financial instruments ex post, prompting creditors to take on excessive risk ex ante.

252 "Legal liability . . . is the sanction for defeated expectations in law." Edwin M. Borchard, International Loans and International Law, 26 ASIL PROC. 135, 163 (1932). See Consortium R.F.C.C. v. Kingdom of Morocco, ICSID Case No. ARB/00/6, Award, para. 69 (Dec. 22, 2003) ("effets substantiels d'une intensité certaine qui réduisent et/ou font disparaître les bénéfices légitimement attendus de l'exploitation des droits objets de ladite mesure à un point tel qu'ils rendent la détention de ces droits inutile"); Saluka Partial Award, supra note 98, paras. 302-04 ("[the investor's] expectations, in order for them to be protected, must rise to the level of legitimacy and reasonableness in light of the circumstances"); Olguín Award, supra note 96, para. 65(b) ([Olguín] "had his reasons (which this Tribunal makes no attempt to judge) for investing in that country, but it is not reasonable for him to seek compensation for the losses he suffered on making a speculative, or at best, a not very prudent, investment").

2531934 PCIJ (ser. A/B) No. 63 (Dec. 12).

254 The LAW AND PROCEDURE OF INTERNATIONAL TRIBUNALS, supra note 112, at 73, 73. Whether a particular bondholder actually knew about the possibility of performance is a matter in equity, not in law. The investment treaty regime does not seek to protect inexperienced retail investors. 
When the majority in the Aspinwall case awarded the face value of the Colombian bonds and interest - even though the bonds were never sold for more than 42 percent of face value - the dissent characterized the result as "a total departure from justice" (the 42 percent figure being their "actual price"). ${ }^{255}$ The U.S. statement of interest in the CIBC Bank case-an important instance of holdout litigation in U.S. courts - came close to suggesting such a standard of compensation in a municipal sovereign debt case: "[sovereign] debt obligations have two values: The original legal contract value and the generally recognized market value." While the United States stopped short of suggesting that nonparticipating creditors - who had purchased their bonds at a 55\% discount—-should be able to recover only the bonds' secondary-market value and not their full face value, the statement of interest noted that "certain creditors-like Dart- . . may seek through litigation to benefit from voluntary debt reduction previously agreed to by the commercial banks ... rather than negotiate a restructuring with the debtor in the orderly manner that [is consistent with U.S. foreign policy and evidenced in the] Brady plans." 256

The appropriate standard of compensation in default is the "generally recognized market value" or "fair market value" — which will typically diverge from the bond's face value. This position is buttressed by recourse to the private law principle of unjust enrichment. ${ }^{257}$ But how should one calculate the generally recognized market value of debt instruments traded on the secondary market? A promising suggestion comes from Sturzenegger and Zettelmeyer: to use the net present value of the old debt after a restructuring, discounted by the yield implicit in the market value of the new debt. ${ }^{258}$ The rationale behind this method of calculating compensation is to treat nonparticipating creditors as if their bonds had the same probability of repayment as new bonds. The underlying goal is to ensure that international investment law does not guarantee repayment of sovereign bonds without proper consideration of the country's creditworthiness. Nonparticipating creditors are thus exposed to the same default risk as participating creditors. Under this approach to computing compensation, nonparticipating

\footnotetext{
${ }^{255}$ Aspinwall v. Venezuela (1885), in MOORE, supra note 30, at 3651, 3664; see Ballistini v. Venezuela, (Fr.Venez. Comm'n 1903), in VenEZUElan ARBITRATIONS OF 1903, at 503 (Jackson H. Ralston ed., 1904). As stated in Boccardo v. Venezuela (1903), in THE LAW AND PROCEDURE Of INTERNATIONAL TRIBUNALS, supra note 112 , at 80,80 :
}

It is a principle of public international law that the internal debt of a state, classified as a public debt, which is subject to speculations current amongst that sort of values which are acquired freely and spontaneously at very different rates of quotations which mark great fluctuations of their rise and fall, can never be subject of international claims in order to obtain their immediate repayment in cash.

256 Statement of Interest of the United States of America in Opposition to the First Amended Complaint in [CIBC Bank \& Trust Co. (Cayman) v. Banco Central do Brasil, 886 F.Supp. 1105 (S.D.N.Y. 1995)], as quoted in Philip J. Power, Sovereign Debt: The Rise of the Secondary Market and Its Implications for Future Restructurings, 64 FORDHAM L.R. 2701, 2752 (1996) (emphasis added). In James v. United Kingdom, 98 Eur. Ct. H.R. (ser. A) para. 54 (1986), the European Court of Human Rights similarly pronounced that

the taking of property without payment of an amount reasonably related to its value would normally constitute a disproportionate interference which could not be justifiable under Article 1 . Article 1 does not, however, guarantee a right to full compensation in all circumstances. Legitimate objectives of 'public interest', such as pursued in measures of economic reform or measures designed to achieve greater social justice, may call for less than reimbursement of the full market value.

257 See, e.g., Christoph H. Schreuer, Unjustified Enrichment in International Law, 22 AM. J. COMP. L. 281 (1974).

258 STURZENEGGER \& ZETTELMEYER, supra note 7, at 4-8. They propose this technique for calculating investor losses in restructurings. It could play a similarly useful role in asesssing fair market value. 
bondholders would not be compensated for the portion of their loss, relative to face value, that is due to default. Crucially, this risk is also borne by participating bondholders.

Nonparticipating bondholders would be compensated, however, for whatever losses might be due to discrimination. At the same time, they would benefit from debt relief provided by participating bondholders. For this reason, the measure of the amount due, calculated as above, represents an upper bound for the legally protected expectation under international law. In practice, compensation due could be lower since that measure does not take into account the improvement in the country's solvency — to which the nonparticipating creditors did not contribute.

This measure of compensation also maintains equal treatment across participating and nonparticipating bondholders. By contrast, preferential treatment of holdout creditors could give rise to MFN claims; for example, complying with an ICSID award requiring payment of the bond's face value could expose a country to BIT claims. Likewise, a large discount on defaulted sovereign bonds would provide strong incentives to initiate ICSID arbitration. In this type of escalating spiral, debt restructurings would quickly unravel.

Secondary-market prices of sovereign bonds tend to collapse when a default is imminent; if a debt restructuring is carried out post default, bond prices will typically have already collapsed. If compensation is based on the bonds' actual value, it is bound to lie substantially below their face value. While "prompt, adequate and effective" compensation for a coercive, postdefault restructuring could be minimal, liability for a similar predefault restructuring would be substantially higher. This divergence in potential liability could discourage preventive restructurings designed to avoid default, despite their desirability when a country's debt levels are clearly unsustainable. The following, concluding section sets forth some preliminary observations on how ICSID intervention in sovereign bonds could change the dynamics of future sovereign debt restructurings.

\section{POLICY IMPLICATIONS OF HOLDOUT ARBITRATION}

Was Du Pont correct to regard international arbitration on sovereign bonds as a Pandora's box? ${ }^{259}$ Some national judgments have appeared to adopt that view even with respect to municipal litigation — and to avoid adjudicating sovereign debt disputes altogether ${ }^{260}$ In recent decades, however, national courts have tended to accept sovereign lending disputes more liberally. ${ }^{261}$ With ICSID, the pendulum could swing away from dispute resolution in domestic courts according to private law, and toward adjudication by international tribunals largely on the basis of international law. This shift could dramatically limit policy flexibility in sovereign

259 See supra note 30.

${ }^{260}$ Courts avoid jurisdiction on the basis of doctrines such as comity or act of state. See generally J. J. FAWCETT, DECLINING JURISDICTION IN PRIVATE INTERNATIONAL LAW: REPORTS TO THE XIVTH CONGRESS OF THE INTERNATIONAL ACADEMY OF COMPARATIVE LAW, ATHENS, AUGUST 1994 (1995). For example, instead of looking at the underlying bond transaction, the Italian Corte di Cassazione, sez. un., 27 May 2005, n.11225, 88 RIVISTA DI DIRITTO INTERNAZIONALE 856 (2005), recently focused on the sovereign acts undertaken in the financial crisis, and declined jurisdiction. The U.S. district court in Allied Bank Int'l v. Banco Credito Agricola de Cartago, 566 F.Supp. 1440 (S.D.N.Y. 1983), aff'd, 733 F.2d 23 (2d Cir. 1984), originally reached a similar result. On rehearing, the circuit court reached the opposite conclusion, 757 F.2d. 516 (2d Cir. 1985).

261 See, for instance, the cases cited supra note 22, where national courts accepted jurisdiction. 
debt crises. For instance, it could hamper the defaulting country's ability to differentiate treatment of creditors according to some criterion of reasonableness. ${ }^{262}$

Would the shift to ICSID in sovereign debt disputes increase bondholder protection? In a world where effective protection of foreign bondholders in municipal courts remains by and large elusive, ICSID could serve as a partial substitute for this institutional shortcoming. Consideration of bondholder claims would move further into the adjudicative, and away from the policy, realm. This change could herald a more consistent treatment of similarly situated bondholders across defaulting countries. The threat of actual enforcement could also, over time, expand the sovereign debt market.

Are ICSID enforcement advantages over municipal court judgments illusory or real? ICSID awards arguably take on a more official character. Sovereign debt adjudication would be transformed from a private, into an international, dispute between states; noncompliance with an ICSID award amounts to an international — and very public — breach. ${ }^{263}$ This change in forum could entail higher reputation costs than ignoring a national court judgment-which could, in turn, hamper the country's future access to financing. Even so, sovereign immunity from execution constrains enforcement of both ICSID awards and national court judgments in similar ways. ${ }^{264}$

If sovereign debt disputes come to be commonly arbitrated under ICSID, a variety of mechanisms could change the dynamics of sovereign debt restructurings in unpredictable ways. On average, the number of sovereign debt disputes, along with the size of claims, is likely to increase. Because of the higher expected recovery (in dollars, taking into account the likelihood of repayment), bondholders will be more inclined to hold out and, bundling their claims whenever possible, to seek payment through arbitration. In addition, the threat of ICSID arbitration could, in itself, be a valuable bargaining chip in a demand for payment.

Does ICSID have jurisdiction to determine a country's payment capacity? Determining debt sustainability would be a prerequisite for entertaining claims arising from defaulted sovereign bonds. Financial necessity could also be a circumstance precluding liability. ${ }^{265}$ Emergency legislation, including debt moratoriums, need to be assessed. Given proper authority and the

${ }^{262}$ Such discretion is often critical for sovereign debt restructurings. Equal treatment of domestic and foreign creditors might be economically undesirable and infeasible politically. See the persuasive arguments in Anna Gelpern \& Brad Setser, What Iraq and Argentina Might Learn from Each Other, 6 CHI. .J. INT'L L. 391 (2005). For a more general argument that investment treaty arbitration introduces unprecendented state liability for business losses due to governmental regulation, see GUS VAN HARTEN, INVESTMENT TREATY ARBITRATION AND PUBLIC LAW (2007).

${ }^{263}$ In general, municipal judgments have no binding force outside the forum's jurisdiction. They require recognition. Under the ICSID Convention, supra note 28, Art. 53, such recognition is automatic, without possibility of substantial review.

${ }^{264}$ Id., Art. 55 ("Nothing in Article 54 shall be construed as derogating from the law in force in any Contracting State relating to immunity of that State or of any foreign State from execution.").

265 See Article 25 of the International Law Commission's Articles on State Responsibility, supra note 154. The Russian Indemnity case, see supra note 184, 7 AJIL at 190, recognized that nonpayment of public debt could be justified in extreme economic and financial circumstances. More recently, the Federal Constitutional Court of Germany denied that a state of necessity could justify the suspension of payment obligations owed to private creditors under sovereign bonds (Joined Case Nos. 2 BvM 1-5/03 \& 1-2/06 (May 8, 2007), at < http://www.bverfg.de/ entscheidungen/ms20070508_2bvm000103.html>; see case report in this issue by Beate Rudolf and Nina Hüfken). A detailed examination of whether such circumstances potentially preclude liability is beyond the scope of these preliminary observations. For a general overview, see Thomas Pfeiffer, Zahlungskrisen ausländischer Staaten im deutschen und internationalen Rechtsverkehr, 102 ZEITSCHRIFT FÜR VERGLEICHENDE RECHTSWISSENSCHAFTEN 141 (2003). 
required methodological tools, ${ }^{266}$ international arbitral tribunals could adjudicate such disputes. ${ }^{267}$ At present, however, ICSID tribunals' authority and ability to decide the question of payment capacity seem tenuous.

Are ICSID tribunals an appropriate forum to provide bondholder protection? In current state practice, some central questions in sovereign debt restructurings are addressed in established political forums. The International Monetary Fund, various multilateral development banks, and the Paris Club are important players. Good examples of questions that are routinely decided by these organizations are debt sustainability, the appropriate amount of debt relief, and the nature of financial assistance to be provided. Sooner rather than later, ICSID arbitration on bonds would conflict with these ongoing institutional tasks.

With sovereign bonds, ICSID would enter a novel and difficult terrain. In the past, countries used political means of one kind or another to address unsustainable sovereign debt burdenswith little involvement of national courts or international tribunals. ${ }^{268}$ Compensation awarded by ICSID tribunals in disputes on public debt could go far beyond what national courts, if they exercised jurisdiction at all, awarded previously. And yet the scope for substantive and enforcement review would be minimal.

There is much room for progressive development of international law on public debt. Current international law provides only minimal protection to sovereign creditors. At the same time, legal machinery to buffer countries against economic and political shocks impairing their payment capacity is largely absent. As a result, sovereign defaults are a perennial source of international tension - as much in 2000 as in 1900. Policymakers and international lawyers have yet to devise viable, long-term solutions.

ICSID arbitration could upset the sovereign debt market's delicate equilibrium. In a world without a legal toolbox for sovereign insolvency, ICSID's focus on creditor protection alone would threaten resolution of future sovereign debt crises. Such a consequence goes against the interests of the creditor majority and also the international community as a whole. Only balanced adjudication of bondholders' and borrowing countries' competing interests will stand a chance of general acceptance and keep the lid firmly shut on this Pandora's box for sovereign finance.

\footnotetext{
266 Tools to assess a country's payment capacity are still in their infancy, and opinions differ on the appropriate methodology.

${ }^{267}$ Plans for reorganizing finances of defaulting states through international arbitration have long currency. The arbitrators would need to examine, inter alia, the country's economic conditions, its projected economic developments, and its budgetary situation. ALBERT, WUARIN, ESSAI SUR LES EMPRUNTS D'ETATS ET LA PROTECTION DES DROITS DES PORTEURS DE FONDS D'ETATS ÉTRANGERS 128-29 (1907). Similarly, JOHN FISCHER WILLIAMS, CHAPTERS ON CURRENT INTERNATIONAL LAW AND THE LEAGUE OF NATIONS 327-29 (1929), would require arbitrators to examine carefully the internal needs of the country. See Drago, supra note 184, at 705.

${ }^{268}$ For instance, U.S. crises in the 1830s and the 1870 s, post-WWI financial adjustment and the Great Depression, the German debt renegotiation after WWII, the Latin American debt crises of the 1980s, and the East Asian and Russian crises of the 1990s.
} 